Article

\title{
Architectural Design and Open Innovation Symbiosis: Insights from Research Campuses, Manufacturing Systems, and Innovation Districts
}

\author{
JinHyo Joseph Yun ${ }^{1, *(\mathbb{D}}$, Xiaofei Zhao ${ }^{1}$, Tan Yigitcanlar ${ }^{2}{ }^{\circledR}$, DooSeok Lee ${ }^{1}$ and HeungJu Ahn ${ }^{1}$ \\ 1 Daegu Gyeongbuk Institute of Science and Technology (DGIST), 333, Techno Jungang Daero, \\ Hyeonpung-myeon, Dalseong-gun, Daegu 42988, Korea; qiaoke@dgist.ac.kr (X.Z.); dslee@dgist.ac.kr (D.L.); \\ heungju@dgist.ac.kr (H.A.) \\ 2 School of Civil Engineering and Built Environment, Queensland University of Technology (QUT), 2 George \\ Street, Brisbane, QLD 4000, Australia; tan.yigitcanlar@qut.edu.au \\ * Correspondence: jhyun@dgist.ac.kr; Tel.: +82-10-6697-8355
}

Received: 2 October 2018; Accepted: 27 November 2018; Published: 29 November 2018

\begin{abstract}
In the age of knowledge-based economies, open innovation has increasing importance. This study aimed to explore the architectural design approaches that can revitalize innovation activities in the era of knowledge-based economies. This paper investigated global case research campuses, manufacturing systems, and innovation districts where architectural design supports innovation activities. This study developed a research framework of architectural design for innovation and applied it in the selected case studies to generate insights. First, the research campuses selected as case studies included Panopticon, DGIST Education and Research Campuses, and Apple Park. Second, the open innovation of manufacturing system architecture was analyzed through the case studies of the Ford Motor Company, Toyota Motor Corporation, and Rolls-Royce Motor Cars. Third, this paper studied the clustered open innovation architectures of Macquarie Park, One North, and Strijp-S Innovation Districts. The findings revealed how tacit knowledge motivates open innovation through the design of manufacturing systems, research campuses, and innovation districts through real examples and mathematical or concept model building.
\end{abstract}

Keywords: open innovation; architectural design; innovation district; cluster; research campus; manufacturing system

\section{Introduction}

Most new knowledge emerges from outside a firm, but often close to the boundaries of firms. There is therefore a risk of overlooking opportunities from the far larger pool of knowledge outside the firm, while failing to prevent leakages of knowledge [1]. As the Fourth Industrial Revolution - that is, the second information technology (IT) revolution, wherein IT advances through all industries-accelerates, there are continuous connections and combinations of technology and the market. This represents open innovation and an open business model [1-3]. The prevalence of open innovation and open business models increases the importance of undocumented tacit knowledge. Tacit knowledge can be achieved through face-to-face contact among people within the same regional innovation system, innovation district, or research campus [4-7].

This study seeks to determine the relationship between open innovation and architectural design. The word 'architecture' here includes the art of building houses, palaces, and temples; ships, cars, railway trucks, and airplanes; as well as domestic, industrial, and trade equipment [8]. In architecture, there are several types such as production systems, schema systems, or linguistic rewrite systems [9]. In computer science, architecture covers all aspects of computer design including instruction set 
architecture, organization or microarchitecture, and hardware [10]. Johann Wolfgang von Goethe once said that "architecture is a frozen music" - treating architecture like structures or monuments. In this study, the concept of architecture is used as a system, schema, or structure that is focused on spatial concepts such campus buildings, manufacturing systems, or innovation districts or clusters. Architecture with this meaning affects diverse human activities such as human relations, human intellectual and emotional activities, human innovation activities, and all related physical functions. The concept of architecture used in this study was a kind of system, schema, or structure, which is focused on spatial concepts such as research campus, manufacturing system, and innovation district.

This study aimed to address the following research questions by focusing on architectural design for open innovation: 'Can an architecture be built up to motivate open innovation through tacit knowledge?' This study analyzed the literature on the relationship between tacit knowledge and open innovation, between individual buildings and smart cities, and between regional innovation systems and open innovation. Through this, an analytical framework was established and case studies were carried out based on the devised analysis structure.

The contents of this paper include a literature review and research framework, the analysis of open innovation in research campus architecture, manufacturing systems, and the innovation district or cluster, and a discussion with our conclusions. Furthermore, this study used a diverse research method such as literature reviews, participatory seeing, mathematical modeling, or case studies.

\section{Literature Review}

Before answering the research question, we have to understand the relationship between architecture for open innovation, and the value of tacit knowledge for open innovation, first through a literature review. Second, a literature review on the relationship between building architecture, and open innovation was done before we studied the DGIST campus building architecture open innovation and manufacturing system architecture open innovation to accumulate as advanced knowledge. Third, a literature review on the relationship between smart city architecture, and open innovation was done before we built up the concept model, and proved "cluster architecture on innovation" by a case study to understand the basic relationship between a cluster, or RIS, and open innovation.

\subsection{The Value of Tacit Knowledge for Open Innovation}

In fact, the concepts of architecture and open innovation are not absolutes that everyone can share. However, while determining its meaning or order may not achieve absolute agreement, an order beyond order may exist between concepts and beyond the concept [11]. The knowledge we have is greater than we may be able to tell. The knowledge gap between knowing and telling is tacit knowledge [12]. Emergence takes over from tacitly knowing the function of producing fundamental innovations [13]. In addition, knowledge acquired from implicit learning procedures is knowledge that, in some raw fashion, is always ahead of the capability of its possessor to explicate it [14].

In the case of an organization, it derives its capability from knowledge that is 'embedded' in its operating routines, has superior capacity for mobilizing and accumulating tacit knowledge, and allows an organic team structure to operate in tandem with a formal hierarchy and stable social organization [15]. The key processes of organizational knowledge creation are the sharing of tacit knowledge for conceptualization and crystallization, which comes from enlarging the knowledge of individuals [16].

New combinations of knowledge about technology or markets are a type of dynamic process from the tacit knowledge of an individual to the explicit knowledge of an organization [16,17]. In addition, managing the process from tacit knowledge to explicit knowledge of an organization is a type of creative chaos of the redundant and requisite, which includes creativity even though it goes with significant complexity and ambiguity $[1,18,19]$. Through tacit knowledge, architectural design for open innovation will act as an innovation infrastructure similar to that in transportation, telecommunications, 
and finance $[1,20]$. The tacit knowledge transfer in architecture plays an indispensable representational role [21-23].

\subsection{Building and Open Innovation}

Ceiling heights can in fact effectively guide the types of processes in which people engage, forming, for instance, the responses of consumers [24]. That is, a high and open space facilitates the creation of new ideas. The automatic effects of deviancy act as cues to creative cognition [25]. In other words, when frequently faced with new things, cognition creativity subsequently increases. A car with broken windows becomes the target of theft more rapidly than a car with an open trunk [26]. In the same context, the structure and form of a building is directly connected to the innovative attitudes of people. The form of architecture directly affects individual cognition. Humans essentially engage in systems thinking. According to the systems view-which posits systems thinking in terms of connectedness, relationships, and context-the essential properties of an organism or a living system are the properties of the whole, which none of the parts have [27].

Under the system view, logic has a feedback loop to assess deviation from the course, counter-steering, and changing the deviation. This cognition process among humans goes via the avenues of creativity through continuous reconfigurations from basically his located building [27]. Therefore, the driving force of evolution is found not in chance events of random mutations, but in life's inherent tendency to create novelty and in the spontaneous emergence of increasing complexity and order in the context of located physical context [27]. Finally, humans, as a system, live in buildings and the open cognition status provided by located building structures necessarily leads to creativity. Similarly, the view through a window may influence recovery from surgery [28]. Including humans, the natural history of innovation can be traced to adjacent possibilities. The tires-to-sandals principle works at all scales and times, including buildings or campuses, if we permit odd and unpredictable initiatives in the adjacent possibilities in order to make nature inventive [29].

\subsection{Smart City and Open Innovation}

The benefits of open innovation may be more readily achieved in regional clusters as the effect of networks on innovation can be magnified by geographic proximity [30,31]. Clusters can be defined as 'geographic concentrations of interconnected companies and institutions in a particular field'. For example, the essential conditions that would increase the likelihood and effectiveness of open innovation strategies at the cluster include network attributes because they have important effects on firm performance in the cluster [31,32].

'Smart cities' is a term that has gained traction in academia, business, and government, describing cities that are increasingly composed of and monitored by pervasive and ubiquitous computing on the one hand, and whose economy and governance are driven by innovation, creativity, and entrepreneurship and enacted by smart people on the other [33-37]. Thus, a smart city is implemented through innovation, creativity, and entrepreneurship in a specific space [38,39]. Additionally, it is directly connected to the spatial context of open innovation. For example, a framework for exploring innovation networks in the development of new city services can become true in smart cities [40]. In addition, according to a new city museum project, leveraging smart open innovation for achieving cultural sustainability is possible [40].

The implementation of the combination of a knowledge city and open innovation is how a smart city is formed [41,42]. Therefore, smart cities with the three environments such as the Internet of Things (IoT), the Internet of Services (IoS), and the Internet of People (IoP) can be treated as open innovation platforms [43]. Examples of smart cities as open innovation platforms are Oulu in Finland; Cambridge, Massachusetts; Friedrichshafen, Germany; the Sense Smart City in Skelleftea, Sweden; and Smart Santander as a European city [43]. As such, one can consider smart cities as environments of open and user-driven innovation for experimenting and validating future Internet-enabled services [44]. If user-driven innovation ecosystems are built through a smart city, citizen engagement will grow, the living lab will be ignited, and open and collaboration innovation will sharply increase. 
According to an empirical analysis that targeted the main cities of Korea, as a city evolves from an industrial city to a knowledge city, its open innovation activities are vitalized [45]. Therefore, building smart cities will leverage open innovation. A smart city approach using open innovation for sharing vision, knowledge, skills, experience, and strategies when designing the delivery of services, goods, and policies in cities is effective, efficient, and sustainable [46].

\subsection{Regional Innovation System and Open Innovation}

Approaches by which to innovate beyond a precinct are valleys, alleys, and roundabouts [47]. RREGIO, which evolved along different trajectories through combinations of political, cultural, and economic forces, may collectively be defined as territories smaller than their state that possess significant local governance capacities and cohesiveness to differentiate them from their state and other regions [48]. Asymmetric regional knowledge capabilities among regional innovation systems and clusters motivate open innovation $[49,50]$. A knowledge economy peruses diversity and the dissemination of the ideas and creativity of its talent base. This has thus led to the acknowledgment of place-making as a major strategy in attracting and retaining the knowledge base into the emerging knowledge and innovation spaces [51]. These places include the locations as well as the physical characteristics of their designs, wider contexts, processes, and images. Moreover, place-making includes the management of firms, spaces, and people.

Ambidextrous clusters, which motivate exploration by universities, large firms, and research laboratories, are exploited by self-financed growth by initial public offerings (IPOs) or assisted in their growth by acquisitions. An ambidextrous cluster is a specialized regional innovation system in the open innovation paradigm [52]. Silicon Valley's large technology firms have pursued an acquisition and development strategy such that startup acquisitions by large firms represented $80.9 \%$ of the exits for VC firms and only $9.1 \%$ for IPOs [52].

The open regional innovation system (ORIS model) is characterized by a firm's adoption of an open innovation strategy in an effort to overcome the boundaries of the firms as well as the region [53]. Like the life science industry park in Emilia-Romagna, ORIS firms do not have research ties within the RIS, but do have national and international research ties. Open and specialized bioregions are innovative, unlike closed specialized bioregions, which are only embryonic [54]. Important knowledge spillover may occur between, rather than within, industries during growth in cities $[55,56]$. In other words, open innovation beyond the borders of regions plays an important role in the growth of the regional innovation system including cities.

\subsection{Research Framework}

This study set the research analysis framework with the aim of exploring and analyzing cases of tacit-knowledge-based open innovation of three architectures: research campus, manufacturing system, and cluster or innovation district (Figure 1). These architectures all belong to spatial the definition of architecture in this study. Additionally, open innovation can become true in three spatial dimensions such as building, smart city, and regions even though these three can overlap. Campus architecture has building open innovation characteristics that partially overlap with the open innovation of the smart city or regional innovation system. Manufacturing architecture has smart city open innovation characteristics, which also partially overlap with the open innovation of building or regional innovation system. Innovation district or cluster architecture has regional innovation system characteristics, which also partially overlap with the open innovation of a building or smart city.

Through this research framework, we explored the open innovation of three target architectures' tacit knowledge embedded through diverse ways. 


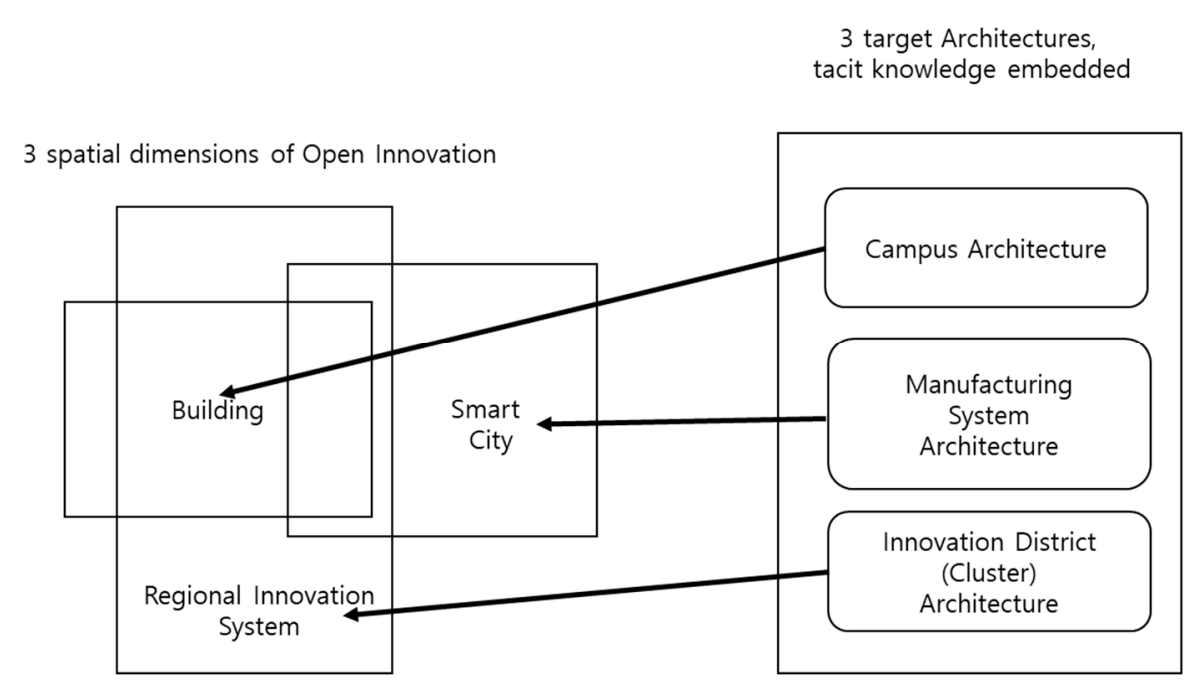

Figure 1. Research framework.

\subsection{Research Scope and Methods}

First, open innovation within the campus architecture was studied through the case studies of Panopticon, DGIST two campus building systems, and the Apple new campus building. Participatory seeing and mathematical modeling methods were used. The main reason to select these campus buildings was the authors' direct experience of open innovation of two DGIST campus building systems. The Panopticon and Apple new campus were selected for a comparison with the DGIST two campus buildings.

Second, the open innovation of manufacturing system architecture was analyzed by the case studies on the manufacturing systems of the Ford Motor Company (Ford), Toyota Motor Corporation (Toyota), and Rolls-Royce Motor Cars (Rolls-Royce). These cases were selected to understand the representative manufacturing systems from an open innovation perspective. The literature review and mathematical modeling methods were used to study the manufacturing system architecture open innovation.

Third, innovation district architecture for open innovation was studied by concept modeling building and analyzing selected three cases. These case innovation districts were: Macquarie Park (Sydney, Australia), One North (Singapore), and Strijp-S (Eindhoven, The Netherlands). These were used to prove the possibility of the concept model on clustered architecture open innovation.

\section{Research Campus Architecture and Open Innovation}

\subsection{Panopticon as a Closed Innovation System}

The term Panopticon is made up of the words "pan" (complete) and "opticon" (see). In 1791, Jeremy Bentham designed a panopticon to observe prisoners more effectively. The Panopticon described in Figure 2 shows that the architecture of the building itself lets prisoners know of the existence and exercise of power [57]. The prisoners in the Panopticon, who were completely observed, were not allowed to communicate with others in adjoining rooms. Of course, they were also unable to communicate with people outside the prison. As a campus, the Panopticon, which implemented absolute power and surveillance, is the perfect case of innovation in a closed status, wherein no type of communication is permitted, exemplifying the implementation of closed innovation through campus architecture. 


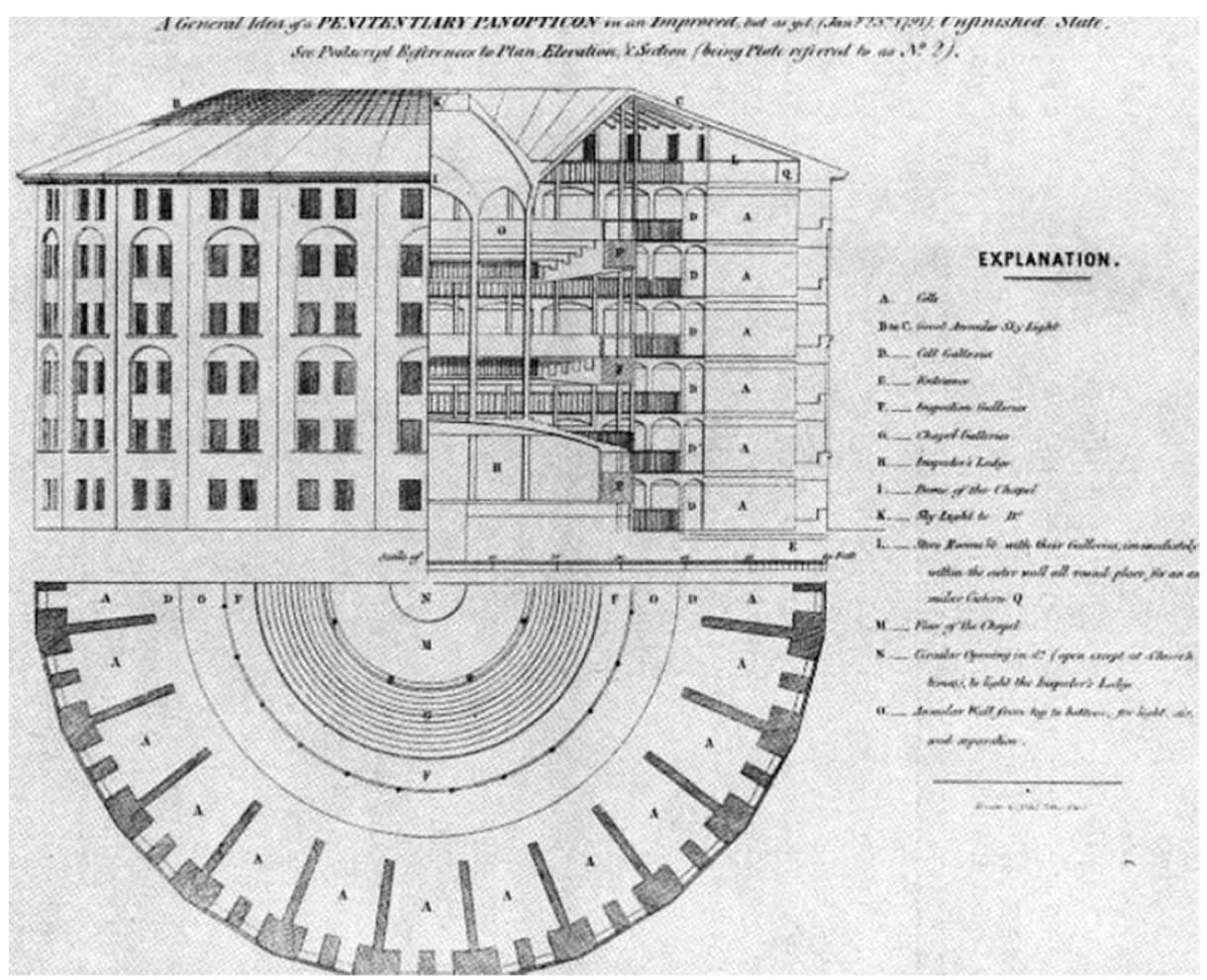

Figure 2. Panopticon. Source: Jeremy Bentham, The Works of Jeremy Bentham (Panopticon, Constitution, Colonies, Codification, 1843).

The Panopticon was not a crowded or noisy prison, as frequently depicted in the pictures of Goya or described in the novels of Howard. However, inside the Panopticon, a prisoner was placed in solitary confinement where a watchman could look at them straight in the eye and both walls of the confinement facility completely blocked communication between prisoners. This structure thoroughly blocked communication among the buildings for humans. Furthermore, self-communication from the inside of an individual was also completely observed. Therefore, considering that internal and external communications for tacit-knowledge-based open innovation were blocked in the Panopticon, it stands as the perfect case of closed innovation in the history of mankind, expressed as a form of campus architecture.

\subsection{Difference between Open Innovation in the DGIST Education Campus and the DGIST Research Campus}

The Daegu Gyeongbuk Institute of Science and Technology (DGIST) has two campuses with different structures and characteristics. The Education Campus is located on the left in Figure 3 and the Research Campus is on the right. At the Education Campus, E1 to E8 are connected. People mainly access the campus from E7 and access each graduate school from E2 to E6. E1 and E8 are connected to E7 and are commonly used by other graduate schools from E2 to E6. In E7, there are many facilities for graduate students and outsiders such as a cafeteria and a stationery store. 


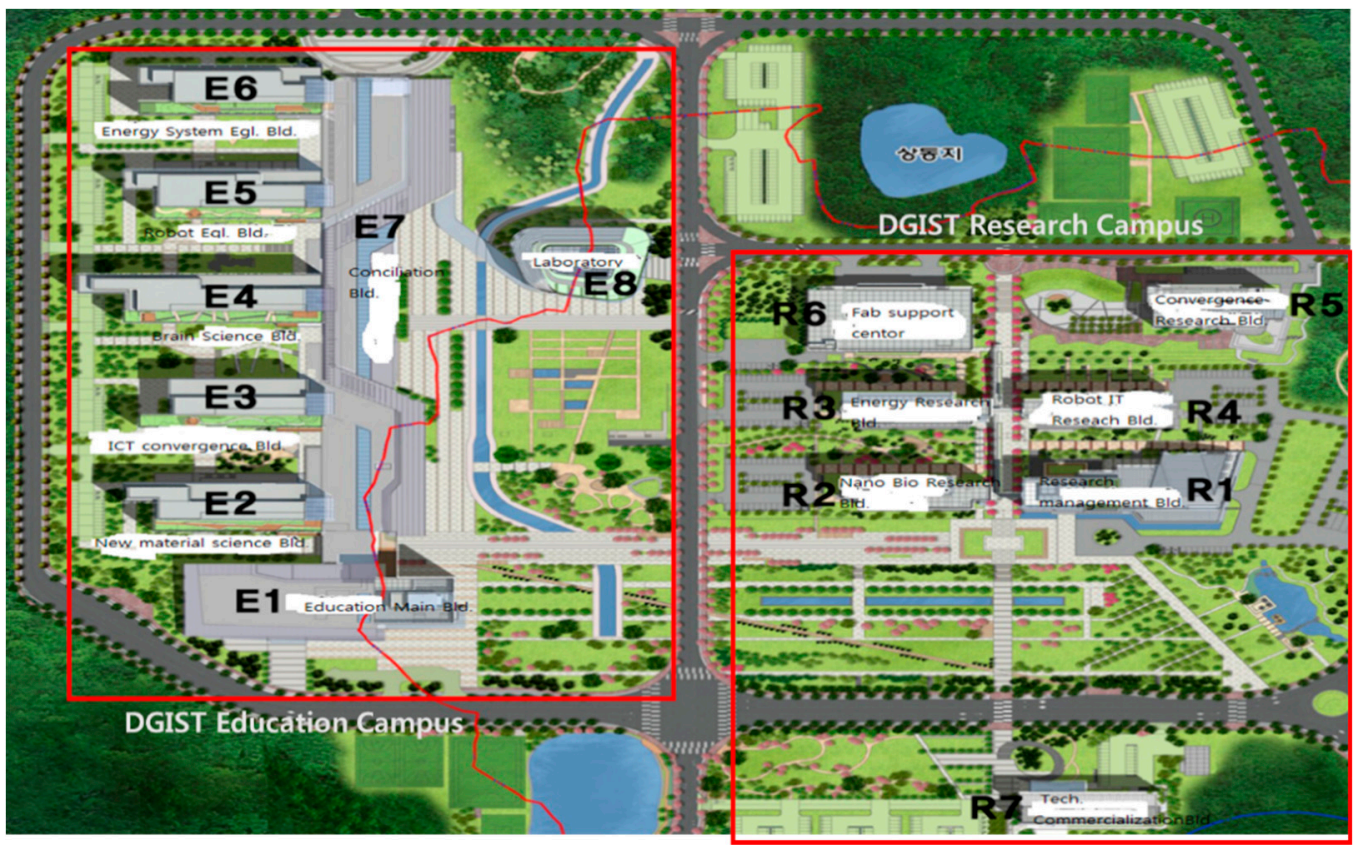

Figure 3. Top view of DGIST Education Campus + DGIST Research Campus. Source: DGIST.

The connections inside the DGIST Education Campus can be more clearly seen in Figure 4. As a connection hub, E7 is used as a passage and a shared building. In addition, there is active communication between colleges on the DGIST Education Campus as well as between the graduate schools on campus and entities elsewhere. This is illustrated by the activation of education or research programs with other departments or graduate schools and in programs with external organizations.

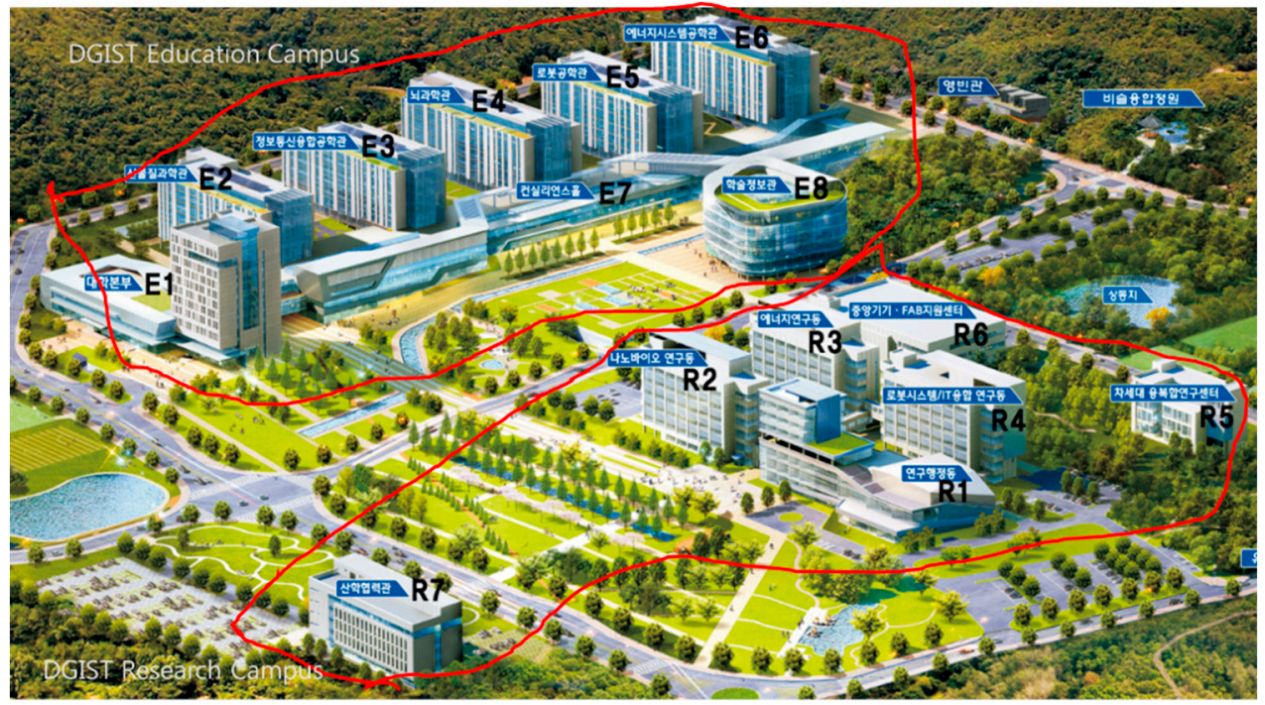

Figure 4. Side view of the DGIST Education Campus + DGIST Research Campus. Source: DGIST.

On the other hand, the DGIST Research Campus was built before 2012, when construction of the Education Campus started. Although the campus is located in a relatively small area compared to the Education Campus (as shown in Figure 3), there are no physical connections between the buildings on the campus. In Figure 4, the buildings from R1 to R6, except R7, were built very close to each other. In fact, most of the only opportunities for researchers on the DGIST Research Campus-where different research departments are located in different buildings - to meet other researchers or outsiders occur in R1, where the cafeteria and the seminar/conference space are located. The separate building R1 is 
simply an isolated space that is not connected to other research department buildings. Thus, the DGIST Research Campus possesses architectural characteristics that do not facilitate communication between research departments for mutual research. Moreover, there is no hub that allows each research department to be active with the outside, despite the fact that the buildings are physically adjacent to each other.

It can be determined that the DGIST Education Campus has a much stronger open innovation structure, given that its structure serves as a passageway, than the DGIST Research Campus, which only has buildings geographically adjacent without a passage. This difference has been fully proven in various cases, though their construction times varied according to a quantitative assessment. For example, here we can assume that businessman A, who is eating pasta in a cafeteria in E7, greets professor $B$ of the robot engineering department who is eating next to him, then they go to E5 to discuss technical developments. After the discussion, A meets professor $C$ of the energy system department in the graduate school at E6 in E7, then talks with C at a café in E8. In the afternoon, A meets researcher $\mathrm{D}$ of the self-driving car research center in R4. After talking with D, A goes down from the eighth floor to the first floor to meet researcher $\mathrm{E}$ of the photovoltaic research center located in R3, then goes to the seventh floor of R3. However, A is unable to meet E because $\mathrm{E}$ has met an outsider and goes to R1 to eat. This scenario shows that the buildings of the Research Campus have a much larger radius of movement despite the fact that they are close to each other. As such, the possibility of meeting others, which is necessary to motivate tacit-knowledge-based open innovation, is much weaker than it is on the Education Campus.

\subsection{Apple Park as an Open Innovation System}

In May of 2017, Apple started moving into its Apple Park campus, which is described in Figure 5. Apple Park is a single-loop-shaped building. If the lights of this building are turned on at night, the four-story building clearly shows its circular shape, as presented in Figure 6. Apple Park has a structural advantage in that all departmental members can interact with each other while walking around inside the building. In other words, it maximizes physical communication between different departments, as required to motivate tacit-knowledge-based open innovation inside the building.

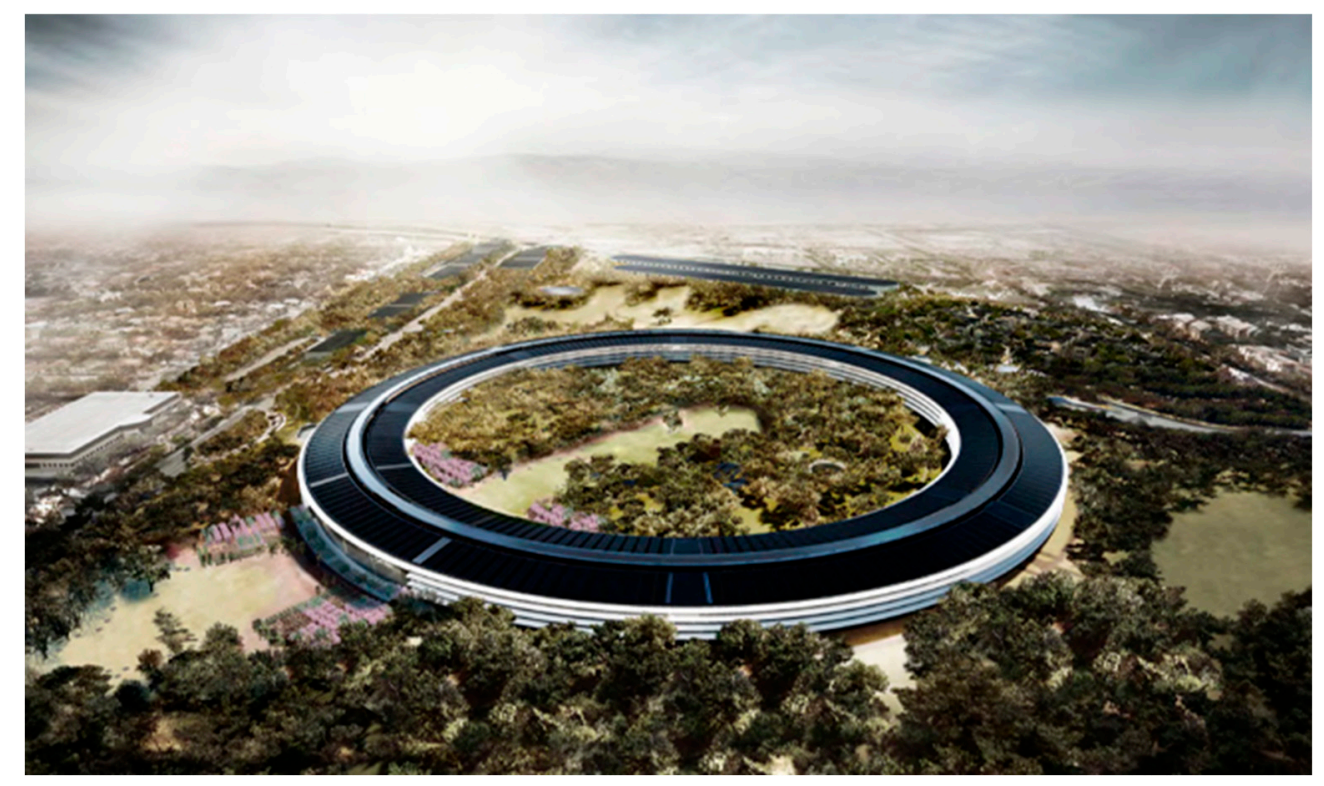

Figure 5. Aerial view of Apple Park. Source: Wikipedia. 


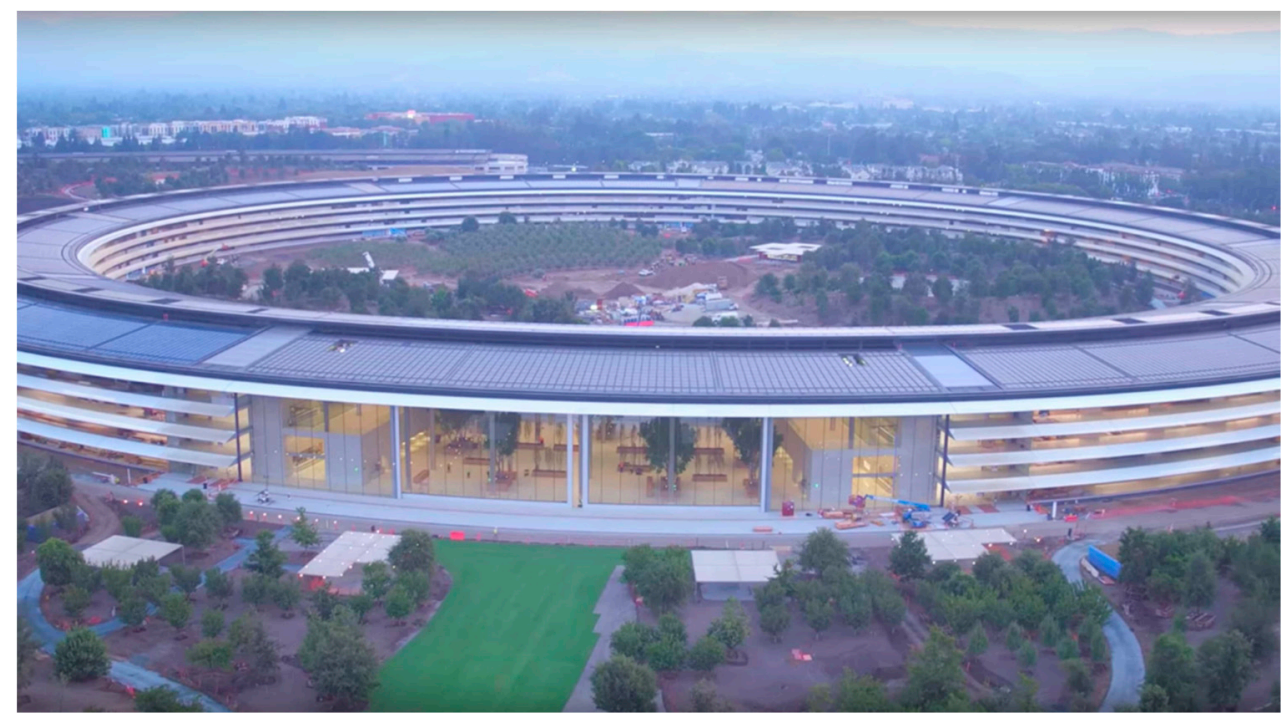

Figure 6. Side view of Apple Park. Source: Wikipedia.

This building structure allows people from all departments and outsiders to actively meet up with each other in a beautiful outdoor café in a garden on the first floor. All Apple staff can communicate with each other in the fitness center located in the basement. Moreover, the Steve Jobs Theater, named after the founder of Apple and located next to the loop-shaped building, creates a cultural hub for communication between the Apple staff and outsiders.

The architectural characteristics of Apple Park are completely in contrast to the concept of the Panopticon. Apple Park allows different members to communicate easily and conveniently with each other regardless of the time and/or place. The structure encourages communication with outsiders in its beautiful cafés, the fitness center, and the theater. It can be argued that the most optimized campus for open innovation in the history of mankind is Apple Park. The loop structure of Apple Park is not the first of its kind. Several previous campus buildings by Apple were loop-shaped so that communication would also be activated as people walked around the inside of the loop-formed building to move to another building. Through this perfect loop construction and its various annexes, Apple Park has become a campus optimized for open innovation. It is expected that the architecture and campus of Apple Park will be a powerful platform for new innovation.

\section{Manufacturing System Architecture and Open Innovation}

\subsection{Ford Factory Manufacturing System as a Closed Innovation System}

Henry Ford was the first to build a manufacturing system for the mass production of automobiles in 1910. In 1910, he founded the first highly organized assembly line system for automobile manufacturing. He organized all elements of the manufacturing system-people, machines, and tool—and arranged them in a continuous system called a conveyor system for the manufacturing of the Model-T automobile. The first principle of assembly is "to place the tools and the men in the sequence of the operation so that each component part shall travel the least possible distance while in the process of finishing to take the work to the men instead of the men to work [58]. The Ford manufacturing system was integrated into the entire production process of flow production. Henry Ford clearly agreed, stating "Now a business, in my way of thinking, is not a machine. It is a collection of people who are brought together to do work and not to write letters to one another" [58].

However, this system did not allow for any variety given its reduction of the necessity of thought on the part of the worker [58]. Ford had the most efficient manufacturing system as it connected all manufacturing elements with one conveyor belt. The shift from Fordism to a regime of flexible accumulation was then considered with particular attention paid to the rise of new technologies and 
new ways of organizing production [59]. New requests or types of diversity, suggested from inside or outside of the manufacturing system, were not accepted. Therefore, the Ford manufacturing system is a type of closed innovation architecture as a manufacturing system. That is, this system has no method, nor can it properly handle new requests and expectations from outside under an open innovation paradigm. Therefore, if we want to move from efficiency to creativeness, a transition to post-Fordism and the Schumpeterian workfare would be necessary [60].

\subsection{Toyota Factory Manufacturing System as a Partially Open Innovation System}

The Toyota Production System (TPS) is based on two basic concepts: 'cost reductions' through the use of just-in-time production (comprised of pull systems, one-piece flows, and leveling), and the 'full utilization of worker's capabilities', which requires a system of respect for people based on minimizing the wasted movements of workers, ensuring their safety, and giving them greater responsibility by allowing them to participate in the running of the factors and in improving their jobs [61].

The Toyota Production System (TPS), now known worldwide as lean production as it redesigned the mass production system, changed the final assembly process into a mixed-model final assembly system to level the demand on suppliers, converted the linear subassembly lines into U-shaped subassembly cells, and redesigned the flow shop product layout into linked-cell manufacturing cells [62]. The lean production of Toyota has the highest degree of concurrency in its engineering process, uses a prolonged target-setting process to explore the design space further and improve the vehicle, and provides "ambiguity" in Toyota's specifications to suppliers, i.e., only a degree of constraint in which it is confident, avoiding future changes [63].

In other words, Toyota introduced external open innovation, wherein the manufacturing method, description, and conditions are newly established according to certain external conditions such as requests by part suppliers and consumers. In addition, its production field selects the most suitable method following requests related to, for instance, work conditions. This means that it also adopts open innovation from inside.

However, according to the any insider's perspective on the realities of the Toyota Production System, it has limited potential for creativity and innovation; requires only narrow professional skills; and promotes worker isolation and harassment, dangerous conditions on the production line, accident cover-ups, excessive overtime, and a poor quality of life for workers [64]. TPS is essentially a sacrifice of efficiency to maintain high flexibility by the contextual reinforcing roles of training and trust in administrative structures, procedures, and rules [65]. In pursuing the profit maximization policy of mass production such as the minimization of costs and inventory, TPS considers together the requests and expectations of the inside and the outside, taking into consideration the standards of its mass production such as profit maximization and inventory and defect minimization. Hence, TPS is based on a compromise between balanced production in overstressing and the pursuit of leanness via the concept of kaizen [66].

The Toyota Way 4P includes open innovation factors such as a long-term thinking philosophy or problem solving with continuous improvements and learning, and closed innovation factors such as eliminating waste processes or treating people and partners with respect considering challenges, growth, and togetherness [67]. Toyota pursues mutual trust between company goals, which include profits and excellent quality, and employee goals that include growth, safe workplaces, and meaningful work. Therefore, Toyota's culture consists of both closed-innovation-based efficiency and open-innovation-based creativeness [68]. The Toyota production system has been summarized as follows. "You can learn a lot, but you're wasting your time if you don't use your own head too" [69].

As such, Toyota's manufacturing method can be considered as partially open innovation production architecture. 


\subsection{Handmade Car Manufacturing System}

The automobile industry is now in an era of subcultural difference, referring to postmodernism and post-Fordism after the age of class distinction, Bourdieu, and craft production. It has entered the era of mass individuality, characterized by the Frankfurt School and Fordism with the arrival of the handmade car manufacturing system [70]. The car industry in the era of subcultural differences pays attention to handmade cars, car styling, modularized eco-innovation, and car-manufacturing-related service industries [71,72].

Rolls-Royce is purported to be one of most luxurious and expensive cars in the world, as some of its parts are said to be handmade [73]. Rolls-Royce tailors cars to its customers [74]. Rolls-Royce's made-to-order service has a perfect robust design process, and manufactures each car according to customer requirements and conditional requests while circulating the process continuously. The handmade car production system allows a production participant with creative ideas to apply the most creative, innovative, and valuable innovation to be externally connected, in addition to their creative ideas and innovations to a customized automobile such as a handmade Rolls-Royce. In the handmade car manufacturing industry, manufacturers are especially moving from continuous improvements to continuous innovations [75]. In addition, modern handmade cars utilize a quick response manufacturing system that responds directly to the requirements of customers [76].

The production system of a handmade car manufacturer such as Rolls-Royce has the characteristics of a form of production architecture that is close to the extreme of open innovation. Robust designs and design processes that are applied to the production of customized automobiles and the creative designs that are realized through the individual requirements of customers are applied through what is termed a circular process. The circular process improves the creativity of open innovation, but decreases the efficiency, in contrast to Ford's conveyor belt or Toyota's U-curve. Therefore, today's luxury handmade automakers are striving to implement ways to optimize their engineering and cut product development cycles through the use of CAD/CAM systems equipped with 3-D solid models and numerically controlled machine tools to reduce areas that are highly inefficient, though these efforts face limits [77].

\section{Innovation District Architecture and Open Innovation}

A cluster is defined as a model with the three elements such as a factory (or R\&D), a house (or market), and a museum (or public space). This section assesses the open innovation of the closed innovation cluster, the partially open innovation cluster, and the open innovation cluster through a thinking experiment based on an open innovation knowledge city and a smart city model [78-81]. This paper uses the popular term 'innovation district' [82-86].

In the experiment, there were three assumptions. First, it was assumed that open innovation in the three-element cluster takes place when the house, i.e., the market consumer, encounters a factory or an R\&D section. This is common as this situation exists in studies of customer open innovation, user open innovation, customer co-creation, and living labs [87-92]. In other words, it is reasonable to conclude that the definition of the concept by which a house, which is a consumer, encounters a factory, leading to open innovation, reflects reality, taking into consideration that if the needs of a consumer, user, or society meet production, new innovation takes place.

Second, it was assumed that a house is willing to visit a museum (or public space) to enjoy the process of finding the museum. In general, citizens like this are willing to enjoy a museum. However, it is assumed that factory people do not enjoy museums to build up a three-factor cluster model. Third, it was assumed that the connections and communication for open innovation occurred in two cases: (a) When a house goes through the factory to the museum, open innovation occurs highly; and (b) When a house goes to the museum directly without any intercept, and a factory exists in the neighborhood of the museum, open innovation occurs half.

The Macquarie Park Innovation District (Sydney) in Figure 7 is Australia's premier innovation location. Home to Macquarie University, Macquarie University Hospital, Macquarie University 
Incubator, and more than 180 large international and 200 small businesses, the vibrant technology park is set to revolutionize the way collaboration and innovation are catalyzed. However, the Macquarie Park Innovation District in Figure 7 is an example of a kind of closed innovation cluster. When people in the house zone go to the museum zone, they do not go through the university and do not have an opportunity to encounter a university. Therefore, in this cluster, the interaction between a house and a university will be limited. This is an example of a closed innovation cluster.
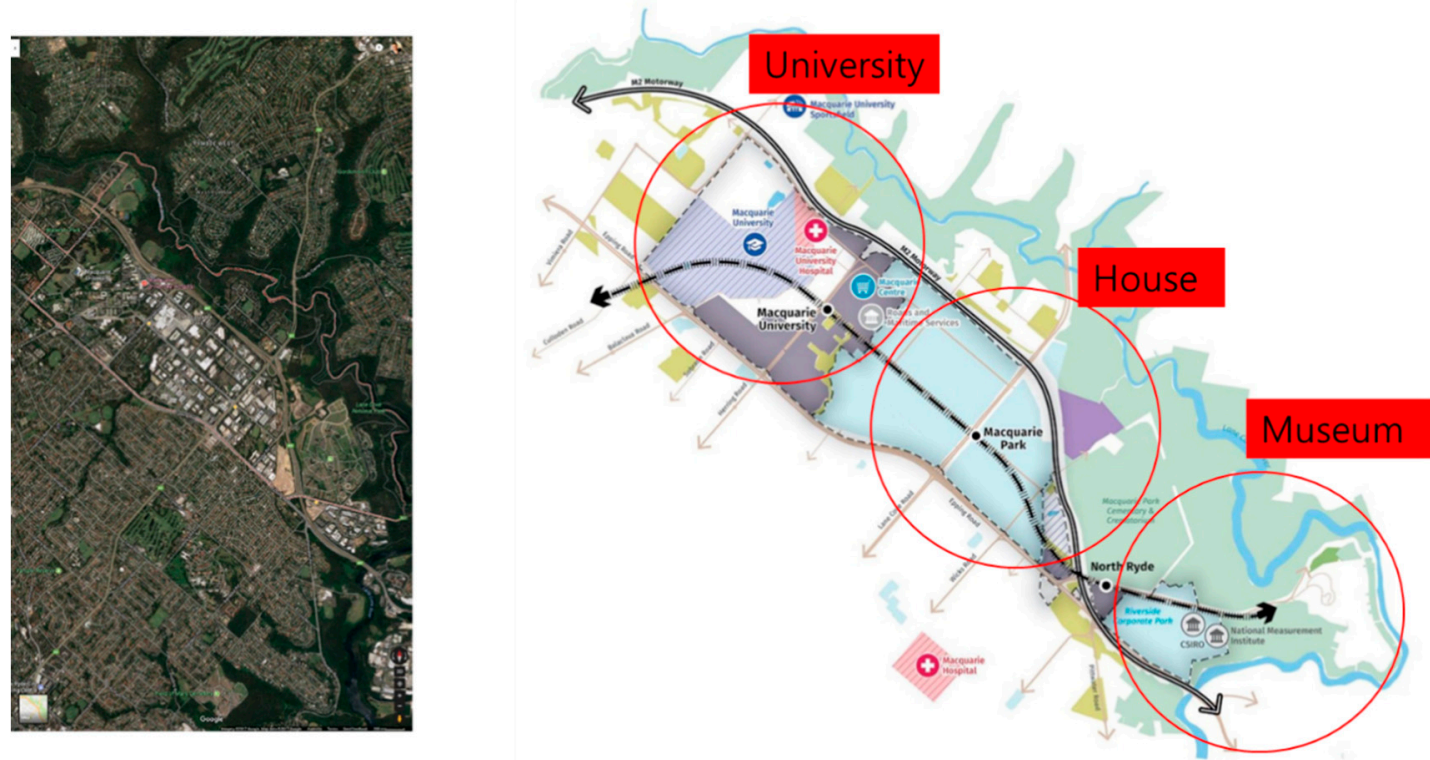

Figure 7. Macquarie Park Innovation District: An A-type closed innovation cluster.

One North Innovation District (Singapore) in Figure 8 is a 200-hectare development strategically positioned in the heart of Singapore. It is designed to host a cluster of world-class research facilities and business park spaces, all built to support the growth of biomedical sciences, information and communication technology (ICT), media, physical sciences, and engineering.
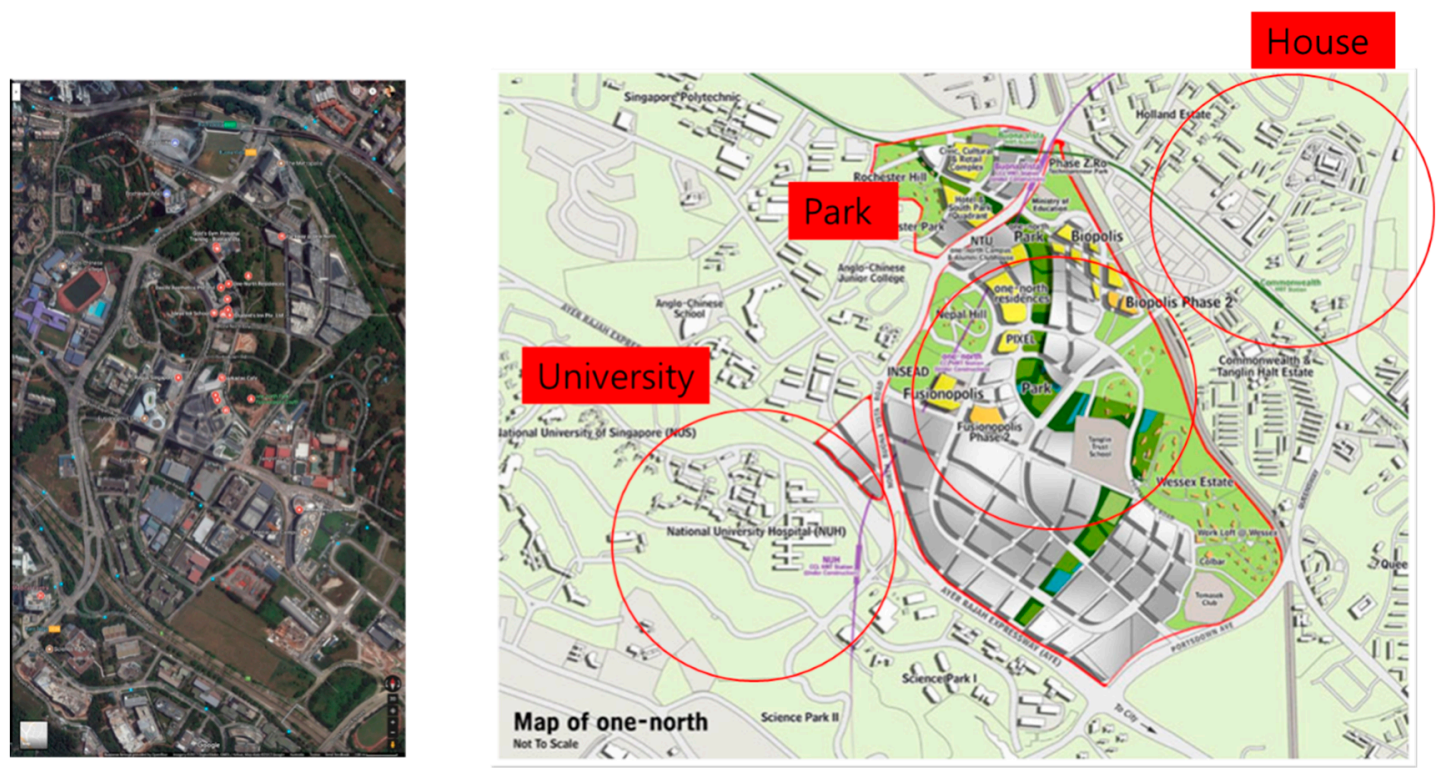

Figure 8. One North Innovation District: B-type half-open innovation cluster.

The One North Innovation District in Figure 8 is an example of a kind of half open innovation cluster. When people in the house zone go to the park zone, although they do not go through 
a university, and they have chances to see the university. Therefore, in this cluster, interaction between a house and a university will be somewhat motivated. This is an example of a half-open innovation cluster.

The Strijp-S Innovation District (Eindhoven, The Netherlands) shown in Figure 9 is a neighborhood and former industrial park in the Eindhoven district of Strijp in the Netherlands. The area formerly belonged to the electronics giant company Philips in the twentieth century. Since 2000, creative companies and housing units have been established in the former industrial buildings. The innovation cluster does not merely contain standard housing, but instead has special and affordable housing concepts including lofts, condos, and urban villas. The Strijp-S Innovation District is an example of a kind of fully open innovation cluster. When people in the house zone go to the entertainment park zone, they must pass through a university. Hence, in this type of cluster, the interaction between the house and the university will be highly motivated. This is an example of a highly open innovation cluster.
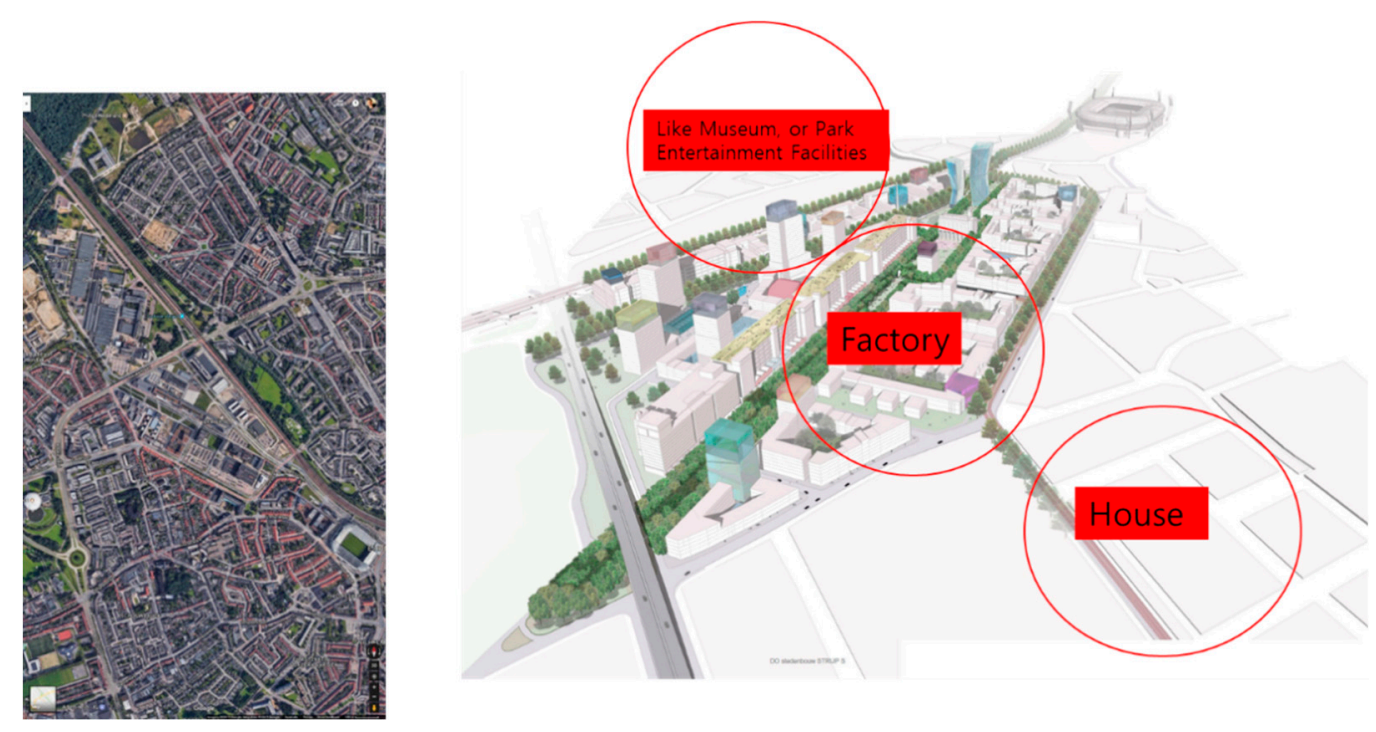

Figure 9. Strijp-S Innovation District: C-type open innovation cluster.

\section{Discussion and Conclusions}

\subsection{Discussion}

The difference between this study and previous studies on open innovation is that this paper directly focused on the spatial aspects of open innovation. Previous studies on open innovation treated the spatial aspects of open innovation indirectly through the discussion of tacit knowledge in firms or clusters. This study did not tackle 'tacit knowledge' in the open innovation process, but 'architectures', which can motivate open innovation through tacit knowledge.

The answer this study found to the question of 'Can an architecture be built up to motivate an open innovation through tacit knowledge?' was yes. First, it is possible to design architecture to activate open innovation in campus architecture. A means of designing complete isolation between internal spaces, as with the Panopticon, is highly unsuitable for innovation through communication. Rather than the architectural design of the DGIST Research Campus, which has buildings arranged adjacently to each other, the architectural design of the DGIST Education Campus, wherein the connections between buildings are in the shape of its architecture, has a better open innovation structure. However, Apple Park, a loop-shaped building, has a vastly superior structure for communication in all of its parts.

The DRC type in Figure 10 makes it very efficient to approach a target room or person. Anyone can go to a target room on the campus without using a passageway. However, at DRC, the possibility 
of meeting another person in the other building is very low. In other words, the possibility of open innovation creativity based on tacit knowledge, which arises when meeting and communicating with others in the other building, does not exist in these buildings, and it is also very low out of the buildings because the areas for movement once outside the buildings are nearly infinite.

The DEC type in Figure 10 can be said to be half efficient when approaching a target room or person. Anyone can go to a target room on campus via the minimal use of a passageway. In addition, in the DEC, there is only a moderate possibility of meeting another person because when using a passageway, there are several opportunities to do so. For the APC type in Figure 10, approaching a target room is done at very low efficiency because a person must pass down a long loop-type aisle to arrive at their target room. However, with regard to creativity, this building is at a very high level because any one person is highly likely to meet others in the loop. The APC strongly motivates tacit-knowledge-based open innovation given these opportunities to meet with others in the loop passageways when compared to DRC or DEC.

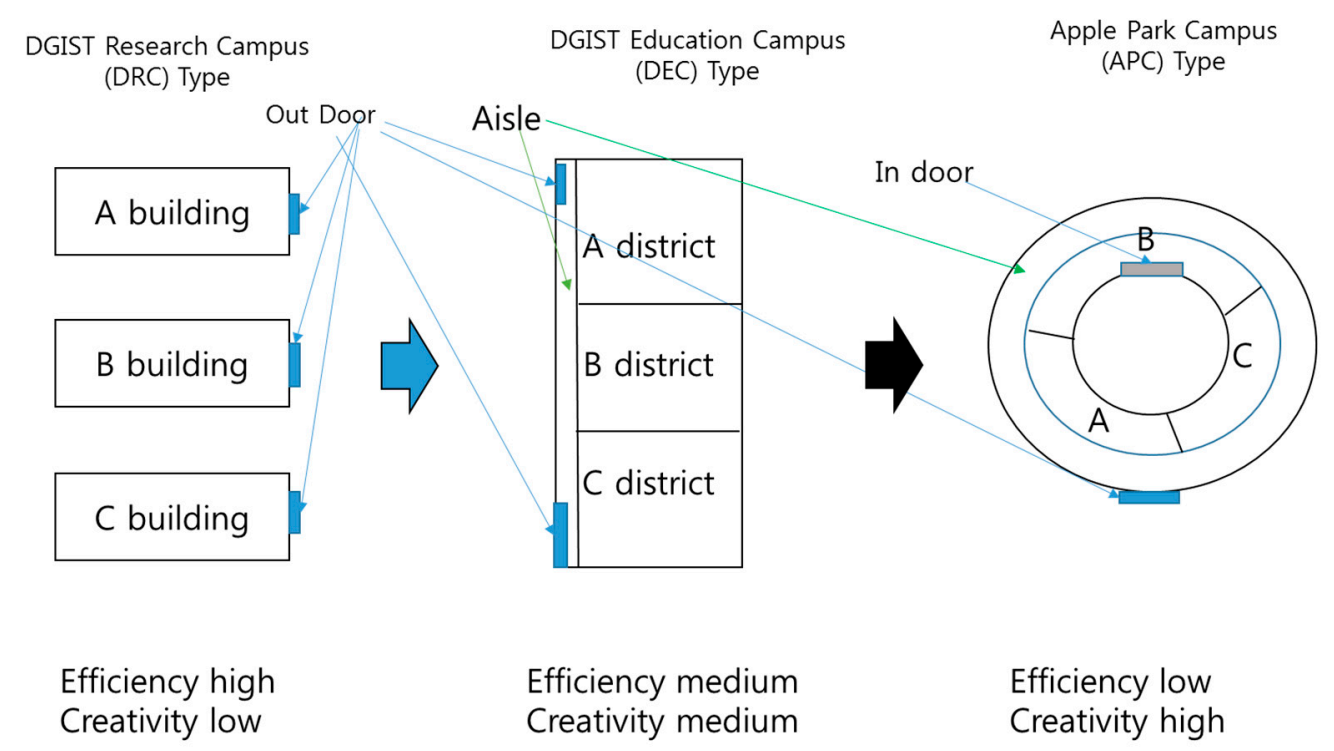

Figure 10. Efficiency and creativity of a campus according to open innovation.

As presented in Appendix A, according to the mathematical model of the possibility of meeting others at the DEC and APC, at the APC, this was 1.39 times greater than at the DEC. In this mathematical modeling, we hypothesized that the increase of meeting each other motivated tacit-knowledge-based open innovation. Hence, the tacit-knowledge-based open innovation on the Apple Park Campus is facilitated by meeting others, which can include other groups inside and outside the organization, which can occur at objectively higher rates than on the DGIST Education Campus.

In addition, in terms of open innovation in campus architecture, the arrangement of spaces such as a restaurant, a café, and a gymnasium on campus can accelerate the open innovation of the entire campus by combining the openness and communication of the campus structure. This leads to the following description. Communication between the internal members of a campus (the open innovation structure of a campus) $\times$ Communication with areas outside of the campus (open innovation arrangement of the external connection facilities of a campus) $=$ The entire open innovation degree of the campus architecture.

Second, it is possible to design areas that activate open innovation in the design of a manufacturing system. The open innovation of the Ford system with its linear conveyor belt is weaker than that of Toyota's lean system with a U-shaped half-conveyor belt. Open innovation that can handle consumer requirements, external environment conditions, and part supplier requirements is possible in Toyota's lean system. The circular non-conveyor belt based Rolls-Royce production system can have the highest open innovation as it is able to handle the requirements of part suppliers and consumers and the 
conditions of the production workers of each product in total. In other words, as manufacturing system architecture is upgraded from a linear-type system through a U-formed system and to a loop-shaped system, its open innovation status increases.

Figure 11 shows that the open innovation of factory production architecture can be very diverse. Unlike the strong closed innovation of the Ford process, Toyota's lean process is closer to being a partially open innovation system. In addition, a handmade approach like the Rolls-Royce production system is a high-level open innovation style that maximizes creativity. The production system architectures of the Ford process, the Toyota lean process, and the handmade process are the linear conveyor-belt type, the U-shaped, and the nonlinear half-conveyor belt type, and the circular non-conveyor belt type where components are continuously circulated and interact, respectively (Figure 11). The analysis of open innovation in automobile production architecture shows that if a system is close to closed innovation, its efficiency rises but its creativity falls. If a system has high open innovation, its creativity increases but its efficiency decreases.

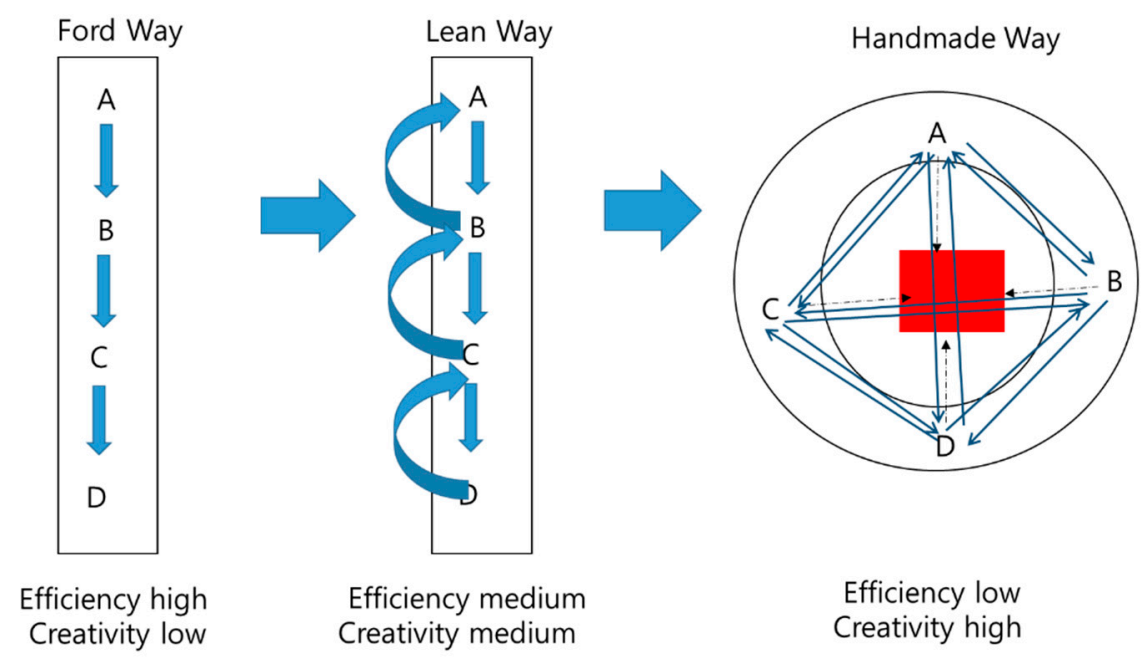

Figure 11. Open innovation in factory production architecture.

According to Appendix B, which presents a mathematical model of the open innovation of manufacturing system architecture, the Ford approach had a higher efficiency than the others. However, with regard to creativity, as measured by network completeness to motivate tacit-knowledge-based open innovation, the handmade way facilitated higher creativity. Thus, if the possibility of meeting increases, the creativity of the manufacturing system increases. The efficiency of this model comes from a decrease in meeting each other, which involves an increase in time and other costs.

Third, it is possible to design areas to activate open innovation when designing a type of cluster architecture. The cluster design by which a house-that is, a house or market-can structurally encounter a factory, that is, a technical innovation sector, will promote creative connections and combinations between technology and the market, or open innovation and the development of an open innovation business model.

In the case of a cluster, A, when a house person goes towards a museum (i.e., a park or entertainment facility, for instance), it is in the opposite direction of a factory (i.e., a university or research and development facility) (Figure 12). That is, during the process of finding a museum by a house person, open innovation wherein a house encounters a factory does not take place. In addition, as a house is opposite to a factory, the possibility of open innovation is low. Thus, cluster A in Figure 12 has the characteristics of a closed innovation cluster. In the case of cluster B, during the process of going towards a museum, a house person does not encounter a factory. However, he has the characteristics of a partially open innovation cluster in that the house person meets a factory through the mediation of a museum. In the case of cluster $C$, when a house person goes towards a museum, the house person encounters the factory directly. So, C, in Figure 12 is an open innovation cluster. If a museum is beyond the factory rather 
than adjacent to the house in the cluster, the possibility of a house person actively encountering a factory increases, and the meeting leads to a connection and combination between new technology and a market, i.e., open innovation.

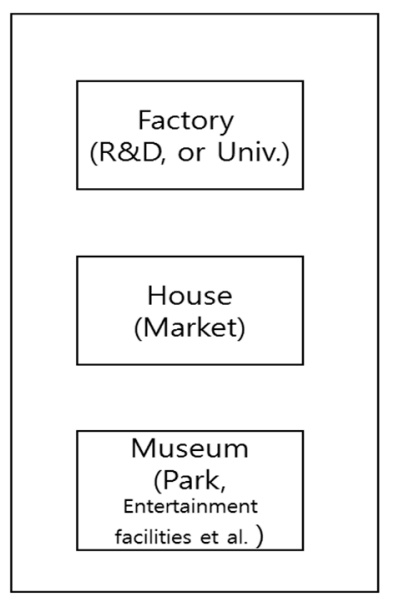

A. Closed Innovation Cluster

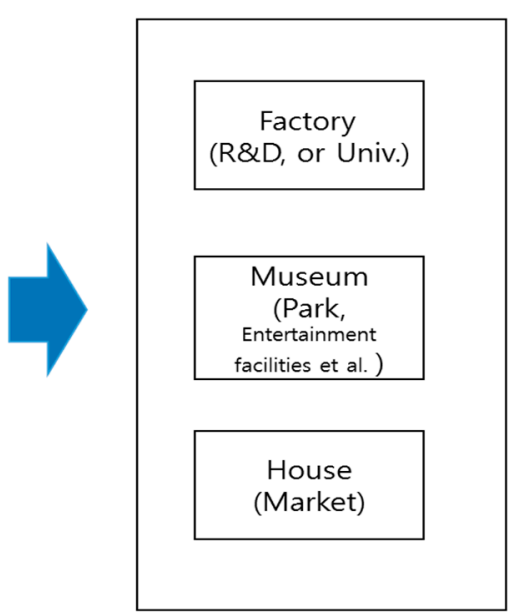

B. Half Open Innovation Cluster

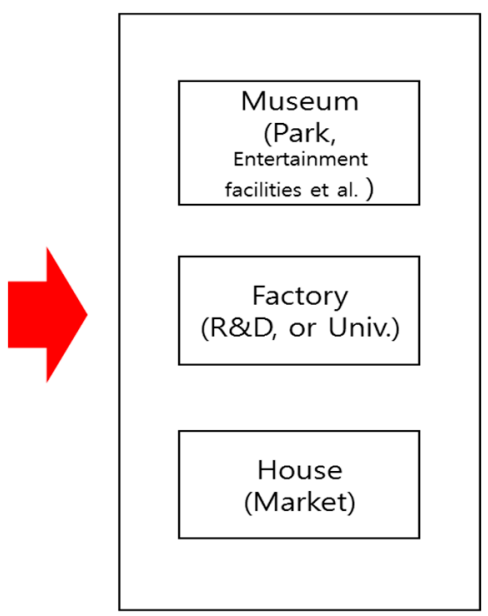

C. Open Innovation Cluster

Figure 12. Three-factor cluster models.

According to our thought experiments and evidence, the structural activation of open innovation at a cluster level is possible. In other words, there are clusters wherein open innovation is structurally activated and those where it is not. When a house person meets a factory directly when it goes to a museum, open innovation of the cluster will be activated.

This study was essentially a kind of conceptual or preliminary research. However, it proves ways to motivate open innovation through three architectures-campus, manufacturing system, and cluster-through real examples and mathematical or concept model building. However, the conditions for generalization beyond the individual cases or mathematical modeling of campus architecture open innovation require further research. In other words, various follow-up studies to find out the general factors that will motivate campus architectural open innovation are required both qualitatively and quantitatively. Through additional case studies, it will be possible to discover the factors or structures that motivate campus architecture open innovation.

Second, the conditions for generalization beyond the individual cases or mathematical modeling of manufacturing system architecture open innovation should be researched in the future. In the Fourth Industrial Revolution, the creativity of the manufacturing system has appeared as a new agenda of the economy. Therefore, diverse follow-up studies of open innovation structures that improve the creativity of a manufacturing system and conditions to maintain the balance between the open innovation structure and production efficiency are needed.

Finally, the structure and conditions for generalization beyond individual cases or concept model of the cluster architecture open innovation also require further research. Most of all, the construction of smart cities is required to motivate the open innovation of tacit knowledge. The concrete ways to open innovation in clusters should be found through additional case studies of clusters in addition to finding the obstacles of open innovation in cluster architectures by cases of success and failure in the accumulation of clusters.

\subsection{Conclusions and Future Research Topics}

Methods of motivating open innovation through tacit knowledge in three architectures-campus, manufacturing system, and cluster-were displayed through real examples and mathematical or concept model building. 
However, generalization beyond the individual cases or mathematical modeling of campus architecture open innovation will require further research. In other words, various follow-up studies to find out the general factors that will motivate campus architectural open innovation are required both qualitatively and quantitatively. Through additional case studies, it will be possible to find the factors or structures that motivate campus architecture open innovation.

Second, the conditions for generalization beyond the individual cases or mathematical modeling of manufacturing system architecture open innovation should be researched in the future. In the Fourth Industrial Revolution, the creativity of manufacturing systems is appearing as a new agenda of the economy. Therefore, diverse follow-up studies on open innovation structures that improve the creativity of a manufacturing system and the conditions to maintain the balance between the open innovation structure and production efficiency are needed.

Third, the structure and conditions for generalization beyond individual cases or the concept model of cluster architecture open innovation also require further research. Most of all, the construction of smart cities is required to motivate the open innovation of tacit knowledge. Concrete methods of open innovation in clusters should be found through additional case studies of clusters in addition to finding out the obstacles of open innovation in cluster architectures through cases of both success and failure in the accumulation of clusters.

Author Contributions: J.J.Y. wrote all of this paper from research question and framework setting to analyzing and simulating as first and corresponding author. D.L. and H.A. did mathematical modeling of this paper. T.Y. prepared all the innovation district examples, and edited this paper. X.Z. did follow up from the starting to the end revision of this research project.

Funding: This research received no external funding.

Acknowledgments: This work was supported by the DGIST R\&D Program of the Ministry of Science and Technology, and ICT (18-IT-01). And this work was partially supported by the Fire Fighting Safety \& 119 Rescue Technology Research and Development Program which was funded to DGIST by the Ministry of Public Safety and Security ok Korea (NEMA-Next Generation-2014-58-2). We would like to thank the DGIST Facility Operation Team for giving us the DGIST architectural drawings, and the Apple Promotion Department for providing all of the necessary information to understand Apple Park.

Conflicts of Interest: The authors declare no conflicts of interest.

\section{Appendix A. Mathematical Model of the Possibility of Meeting Others at the DEC and APC}

Let us define the measure, denoted by $\mathrm{Col}$ (Space), of the collisions between different agents within an architecture by:

$$
\operatorname{Col}(\text { Space }):=\sum_{\text {space }_{i}}{\text { CollisionProb }\left(\text { Space }_{i}\right) * \text { Area }\left(\text { Space }_{i}\right)} .
$$

Here, CollisionProb $\left(\right.$ Space $\left._{i}\right)$ refers to the collision probability or meeting probability of different agents at the place Space $_{i}$, as given by the discretization of the passageways. This is a measure according to which two agents meet in Space $_{i}$. It is defined as follows:

$$
\text { CollisionProb }\left(\text { Space }_{i}\right)=\sum \text { agent }_{j}, \text { agent }_{k} \in \text { Agents }_{\text {Prob }}\left(\text { agent }_{j} \in \text { Space }_{i}\right) * \operatorname{Prob}_{\left(\text {agent }_{k} \in \text { Space }_{i}\right)} .
$$

For a more exact measure, we should consider the temporal distribution of agents in each space segment. However, for simplicity, we only consider the spatial factors here.

Let us calculate the collision measure for the case of DEC (DGIST Education Campus), as presented in Figure 8. 


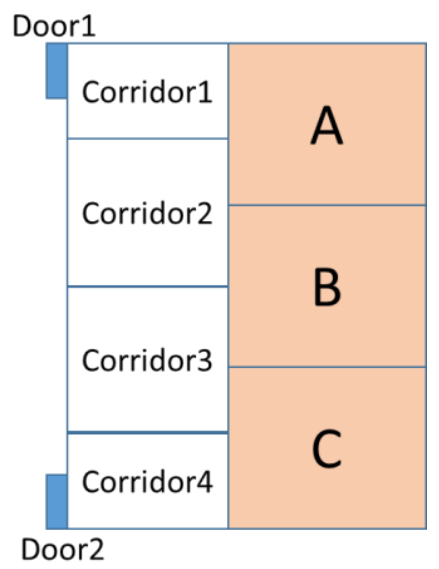

Figure A1. Campus Building with Connection Corridor.

We assume that the probability of a person from district A coming in and out of Door1 is $2 / 3$, as denoted by $\mathrm{P}(\mathrm{A}$, door 1$)=\frac{2}{3}$, and the probability of using Door 2 is $1 / 3$, as denoted by $\mathrm{P}(\mathrm{A}$, door 2$)=\frac{1}{3}$. Similarly, let us assume that $\mathrm{P}(\mathrm{B}$, door 1$)=\frac{1}{2}=\mathrm{P}(\mathrm{B}$, door 2$)$ and $\mathrm{P}(\mathrm{C}$, door 1$)=\frac{1}{3}, \mathrm{P}(\mathrm{C}$, door 2$)=\frac{2}{3}$.

Thus, the collision probability along Corridor1 is given by

$$
\begin{aligned}
& \text { CollisionProb }(\text { Corridor } 1) \\
& =\operatorname{Prob}_{\left(\text {agent }_{A} \in \text { Corridor } 1\right) \cdot \operatorname{Prob}\left(\text { agent }_{B} \in \text { Corridor } 1\right)} \\
& +\operatorname{Prob}_{\left(\text {agent }_{A} \in \text { Corridor } 1\right) \cdot \operatorname{Prob}\left(\text { agent }_{C} \in \text { Corridor } 1\right)} \\
& +\operatorname{Prob}_{\left(\text {agent }_{B} \in \text { Corridor } 1\right) \cdot \operatorname{Prob}\left(\text { agent }_{C} \in \text { Corridor } 1\right)} \\
& =\frac{2}{3} \cdot \frac{1}{2}+\frac{2}{3} \cdot \frac{1}{3}+\frac{1}{2} \cdot \frac{1}{3}=\frac{13}{18}
\end{aligned}
$$

We can also calculate

$$
\text { CollisionProb(Corridor } 2)=\frac{1}{3} \cdot \frac{1}{2}+\frac{1}{3} \cdot \frac{1}{3}+\frac{1}{2} \cdot \frac{1}{3}=\frac{4}{9}
$$

According to the symmetry of the positions and probabilities,

$$
\begin{aligned}
& \text { CollisionProb }(\text { Corridor } 4)=\text { CollisionProb }(\text { Corridor } 1)=\frac{13}{18} \\
& \text { CollisionProb }(\text { Corridor } 3)=\operatorname{Collision} \operatorname{Prob}(\text { Corridor } 2)=\frac{4}{9} .
\end{aligned}
$$

For the purpose of comparison, if we use the relative ratio of the area but not the actual area, i.e., Area $($ Corridor 1$)=\frac{1}{6}$, the collision measure in the DEC is given by

$$
\mathrm{Col}(\mathrm{DEC})=\frac{13}{18} \cdot \frac{1}{6}+\frac{4}{9} \cdot \frac{2}{6}+\frac{4}{9} \cdot \frac{2}{6}+\frac{13}{18} \cdot \frac{1}{6}=\frac{29}{54} \approx 0.54 .
$$

Similarly, we can calculate the collision measure at the APC. Let us denote the clockwise direction to Door1 by door $1^{+}$and the counter-clockwise direction to Door1 by door $1^{-}$. We assume that $\mathrm{P}\left(\mathrm{A}\right.$, door $\left.^{+}\right)=\frac{1}{4}, \mathrm{P}\left(\mathrm{A}\right.$, door $\left.^{-}\right)=\frac{3}{4}, \mathrm{P}\left(\mathrm{B}\right.$, door $\left.^{+}\right)=\frac{1}{2}=\mathrm{P}\left(\mathrm{B}, \operatorname{door}^{-}\right)$and $\mathrm{P}\left(\mathrm{C}, \operatorname{door}^{+}\right)=$ $\frac{3}{4}, \mathrm{P}\left(\mathrm{C}, \mathrm{door}^{-}\right)=\frac{1}{4}$. 


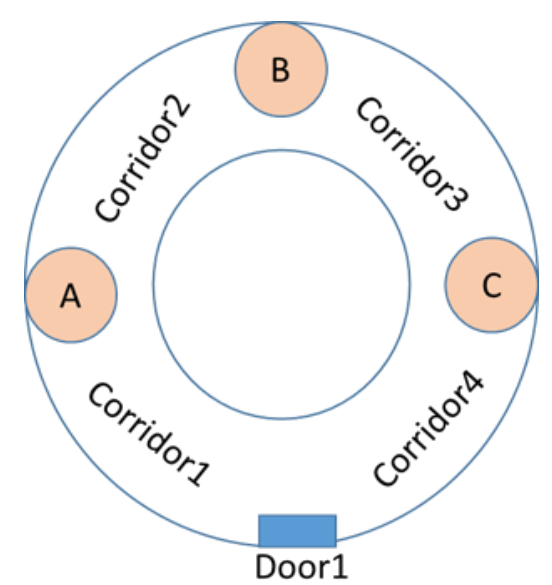

Figure A2. Campus Building in Circle Type.

The spaces are divided into four annular sectors, Corridor $_{i},(i=1,2,3,4)$, with identical areas. Hence, we have

$$
\begin{aligned}
& \text { CollisionProb }(\text { Corridor } 1) \\
& =\operatorname{Prob}\left(\text { agent }_{A} \in \text { Corridor } 1\right) \cdot \operatorname{Prob}\left(\text { agent }_{B} \in \text { Corridor } 1\right) \\
& +\operatorname{Prob}\left(\text { agent }_{A} \in \text { Corridor } 1\right) \cdot \operatorname{Prob}\left(\text { agent }_{C} \in \text { Corridor } 1\right) \\
& +\operatorname{Prob}\left(\text { agent }_{B} \in \text { Corridor } 1\right) \cdot \operatorname{Prob}\left(\text { agent }_{C} \in \text { Corridor } 1\right) \\
& =\frac{3}{4} \cdot \frac{1}{2}+\frac{3}{4} \cdot \frac{1}{4}+\frac{1}{2} \cdot \frac{3}{4}=\frac{15}{16}=\operatorname{CollisionProb}(\text { Corridor } 4) .
\end{aligned}
$$

In addition, we can calculate

$$
\text { CollisionProb(Corridor } \left.2)=\frac{1}{4} \cdot \frac{1}{2}+\frac{1}{4} \cdot \frac{1}{4}+\frac{1}{2} \cdot \frac{3}{4}=\frac{9}{16}=\text { CollisionProb(Corridor } 3\right) \text {. }
$$

Thus, if we use the relative ratio of each corridor in the entire corridor, we have the measure of collision at the APC as

$$
\operatorname{Col}(\mathrm{APC})=\frac{15}{16} \cdot \frac{1}{4}+\frac{9}{16} \cdot \frac{1}{4}+\frac{9}{16} \cdot \frac{1}{4}+\frac{15}{16} \cdot \frac{1}{4}=\frac{3}{4} \approx 0.75
$$

\section{Appendix B. Mathematical Model of Open Innovation in Manufacturing System Architecture}

In the mathematical field of graph theory, a complete digraph is a directed graph where every pair of distinct vertices is connected by a pair of unique edges (one in each direction) [93]. We will use this concept to measure the creativity or cooperativeness of a network, although there are many ways to define this.

Let us define the degree of creativity of a network $N$, denoted by $\operatorname{Coop}(\mathrm{N})$, by the degree of completeness of the network:

$$
\operatorname{Coop}(\mathrm{N})=\frac{|\mathrm{E}(\mathrm{N})|}{\left|E\left(K_{N}\right)\right|}
$$

Here, the numerator $|\mathrm{E}(\mathrm{N})|$ is the number of the direct edges of the network $N$, and the denominator $\left|E\left(K_{N}\right)\right|$ refers to the number of the direct edges of a complete digraph with the same number of nodes as the network $\mathrm{N}$.

For example, we can compute the degree of creativity of the network in Figure 12 as follows:

$$
\begin{gathered}
\operatorname{Coop}(\text { Ford Way })=\frac{3}{12}, \operatorname{Coop}(\text { Toyota Lean })=\frac{6}{12}, \\
\operatorname{Coop}(\text { Handmade Way })=\frac{12}{12} .
\end{gathered}
$$


For the measure of the efficiency of a production network, we can consider the shortness and simplicity of the manufacturing process from input to output. Let us define the measure of the efficiency of a production network $\mathrm{N}$, denoted by $\operatorname{Eff}(\mathrm{N})$, as

$$
\operatorname{Eff}(\mathrm{N})=\frac{1}{\sum_{p \in P(N)} \operatorname{Length}(p)},
$$

where $P(N)$ is the set of all paths from the input to output in the network $N$ and $\operatorname{Length}(p)$ is the number of complexities of the working patterns of the path $p$ in $P(N)$, as explained in the case shown in Figure 12:

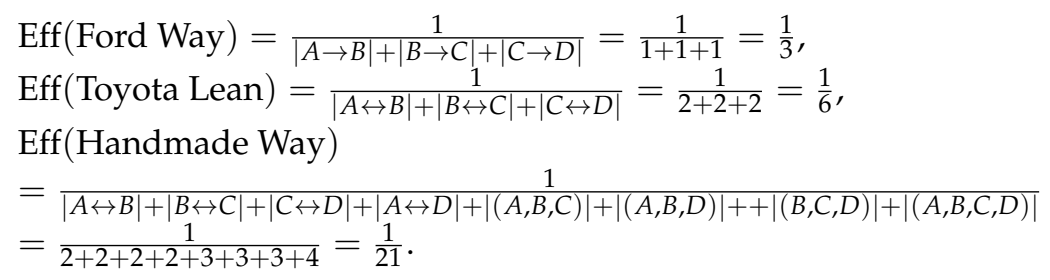

Here, $|A \rightarrow B|$ counts as 1 because there is only one directed path from $\mathrm{A}$ to $\mathrm{B}$. In contrast, $|A \leftrightarrow B|$ counts as two given that there is a two-way directed path from $\mathrm{A}$ to $\mathrm{B}$. Additionally, $(A, B, C)$ means that $\mathrm{A}, \mathrm{B}$, and $\mathrm{C}$ can work together. Hence, the complexity of $|(A, B, C)|$ is defined as three, and so on.

\section{References}

1. Chesbrough, H.W. Open Innovation: The New Imperative for Creating and Profiting from Technology; Harvard Business Press: Boston, MA, USA, 2003.

2. Gassmann, O.; Enkel, E. Towards a Theory of Open Innovation: Three Core Process Archetypes. In Proceedings of the R\&D Management Conference (RADMA) 2004, Lisbon, Portugal, 7-9 July 2004.

3. Yun, J.J. The Way from Open Innovation to Business Model Business Model Design Compass; Springer: London, UK, 2017; pp. 151-162.

4. Gertler, M.S. Tacit Knowledge and the Economic Geography of Context, or the Undefinable Tacitness of Being (There). J. Econ. Geogr. 2003, 3, 75-99. [CrossRef]

5. Lawson, C.; Lorenz, E. Collective Learning, Tacit Knowledge and Regional Innovative Capacity. Reg. Stud. 1999, 33, 305-317. [CrossRef]

6. Esmaeilpoorarabi, N.; Yigitcanlar, T.; Guaralda, M. Towards an urban quality framework: Determining critical measures for different geographical scales to attract and retain talent in cities. Int. J. Knowl. Based Dev. 2016, 7, 290-312. [CrossRef]

7. Esmaeilpoorarabi, N.; Yigitcanlar, T.; Guaralda, M. Place quality and urban competitiveness symbiosis? A position paper. Int. J. Knowl.-Based Dev. 2016, 7, 4-21. [CrossRef]

8. Corbusier, L. The Modulor and Modulor 2; Springer Science \& Business Media: London, UK, 2004 ; Volume 1.

9. Anderson, J.R. The Architecture of Cognition; Psychology Press: Hove, UK, 2013.

10. Hennessy, J.L.; Patterson, D.A. Computer Architecture: A Quantitative Approach; Elsevier: Amsterdam, The Netherlands, 2011.

11. Von Savigny, E. Ludwig Wittgenstein: Philosophische Untersuchungen; Walter de Gruyter: Berlin, Germany, 1998; Volume 13.

12. Polanyi, M. Tacit knowing: Its bearing on some problems of philosophy. Rev. Mod. Phys. 1962, 34, 601-605. [CrossRef]

13. Polanyi, M. The Tacit Dimension; University of Chicago Press: Chicago, IL, USA, 2009.

14. Reber, A.S. Implicit learning and tacit knowledge. J. Exp. Psychol. Gen. 1989, 118, 219. [CrossRef]

15. Lam, A. Tacit knowledge, organizational learning and societal institutions: An integrated framework. Organ. Stud. 2000, 21, 487-513. [CrossRef]

16. Nonaka, I.; Byosiere, P.; Borucki, C.C.; Konno, N. Organizational knowledge creation theory: A first comprehensive test. Int. Bus. Rev. 1994, 3, 337-351. [CrossRef] 
17. Hamdani, J.; Wirawan, C. Open innovation implementation to sustain Indonesian SMEs. Procedia Econ. Financ. 2012, 4, 223-233. [CrossRef]

18. Yigitcanlar, T.; Metaxiotis, K.; Carrillo, F.J. (Eds.) Building Prosperous Knowledge Cities: Policies, Plans and Metrics; Edward Elgar Publishing: Cheltenham, UK, 2012.

19. Lönnqvist, A.; Käpylä, J.; Salonius, H.; Yigitcanlar, T. Knowledge that matters: Identifying regional knowledge assets of the Tampere region. Eur. Plan. Stud. 2014, 22, 2011-2029. [CrossRef]

20. Estrin, D.; Sim, I. Open mHealth Architecture: An Engine for Health Care Innovation. Science 2010, 330, 759-760. [CrossRef] [PubMed]

21. Henderson, R.M.; Clark, K.B. Architectural Innovation: The Reconfiguration of Existing Product Technologies and the Failure of Established Firms. Adm. Sci. Q. 1990, 35, 9-30. [CrossRef]

22. Mitchell, W.J. City of Bits: Space, Place, and the Infobahn; MIT Press: Cambridge, MA, USA, 1996.

23. Millar, C.C.; Choi, C. Development and knowledge resources: A conceptual analysis. J. Knowl. Manag. 2010, 14, 759-776. [CrossRef]

24. Meyers-Levy, J.; Zhu, R. The Influence of Ceiling height: The Effect of Priming on the Type of Processing that People Use. J. Consum. Res. 2007, 34, 174-186. [CrossRef]

25. Förster, J.; Friedman, R.S.; Butterbach, E.B.; Sassenberg, K. Automatic Effects of Deviancy Cues on Creative Cognition. Eur. J. Soc. Psychol. 2005, 35, 345-359. [CrossRef]

26. Kelling, G.L.; Coles, C.M. Fixing Broken windows: Restoring Order and Reducing Crime in our Communities; Simon and Schuster: New York, NY, USA, 1997; Volume 26.

27. Capra, F. The Web of Life; Audio Renaissance Tapes: Duplin, North Carolina, 1996; Volume 54, p. 22.

28. Ulrich, R. View Through a Window May Influence Recovery. Science 1984, 224-225. [CrossRef]

29. Johnson, S. Where Good Ideas Come From: The Natural History of Innovation; Wiley Online Library: Hoboken, NJ, USA, 2011; Volume 29.

30. Porter, M.E. Clusters and the New Economics of Competition. Harv. Bus. Rev. 1998, 76, 77-90. [PubMed]

31. Simard, C.; West, J. Knowledge Networks and the Geographic Locus of Innovation. In Open Innovation: Researching a New Paradigm; OUP Oxford: Oxford, UK, 2006; pp. 220-240.

32. Beckman, C.M.; Haunschild, P.R. Network Learning: The Effects of Partners' Heterogeneity of Experience on Corporate Acquisitions. Adm. Sci. Q. 2002, 47, 92-124. [CrossRef]

33. Kitchin, R. The Real-Time City? Big Data and Smart Urbanism. GeoJournal 2014, 79, 1-14. [CrossRef]

34. Yigitcanlar, T.; Kamruzzaman, M.; Buys, L.; Ioppolo, G.; Sabatini-Marques, J.; Costa, E.; Yun, J. Understanding 'smart cities': Intertwining development drivers with desired outcomes in a multidimensional framework. Cities 2018, 81, 145-160. [CrossRef]

35. Yigitcanlar, T.; Foth, M.; Kamruzzaman, M. Towards post-anthropocentric cities: Reconceptualising smart cities to evade urban ecocide. J. Urban Technol. 2018. [CrossRef]

36. Yigitcanlar, T.; Kamruzzaman, M. Does smart city policy lead to sustainability of cities? Land Use Policy 2018, 73, 49-58. [CrossRef]

37. Yigitcanlar, T.; Kamruzzaman, M. Smart cities and mobility: Does the smartness of Australian cities lead to sustainable commuting patterns? J. Urban Technol. 2018. [CrossRef]

38. Yigitcanlar, T. Smart cities: An effective urban development and management model? Aust. Plan. 2015, 52, 27-34. [CrossRef]

39. Yigitcanlar, T. Technology and the City: Systems, Applications and Implications; Routledge: New York, NY, USA, 2016.

40. Errichiello, L.; Micera, R.J.S. Leveraging Smart Open Innovation for Achieving Cultural Sustainability: Learning from a New City Museum Project. Sustainability 2018, 10, 1964. [CrossRef]

41. Yigitcanlar, T.; Lee, S. Korean ubiquitous-eco-city: A smart-sustainable urban form or a branding hoax? Technol. Forecast. Soc. Chang. 2014, 89, 100-114. [CrossRef]

42. Yun, J.J.; Leem, Y.T. The Smart City as an Open Innovation Knowledge City. Int. J. Knowl.-Based Dev. 2016, $7,103$.

43. Hernández-Muñoz, J.M.; Vercher, J.B.; Muñoz, L.; Galache, J.A.; Presser, M.; Gómez, L.A.H.; Pettersson, J. Smart Cities at the Forefront of the Future Internet. In The Future Internet Assembly; Springer: Munchen, Germany, 2011. 
44. Schaffers, H.; Komninos, N.; Pallot, M.; Trousse, B.; Nilsson, M.; Oliveira, A. Smart Cities and the Future Internet: Towards Cooperation Frameworks for Open Innovation. In The Future Internet; Springer: Berlin/Heidelberg, Germany, 2011; pp. 431-446.

45. Yun, J.J.; Jeong, E.; Yang, J. Open Innovation of Knowledge Cities. J. Open Innov. Technol. Market Complex. 2015, 1, 16. [CrossRef]

46. Paskaleva, K.A. The Smart City: A Nexus for Open Innovation? Intell. Build. Int. 2011, 3, 153-171. [CrossRef]

47. Yigitcanlar, T.; Bulu, M. Dubaization of Istanbul: Insights from the knowledge-based urban development journey of an emerging local economy. Environ. Plan. A 2015, 47, 89-107. [CrossRef]

48. Cooke, P.; Uranga, M.G.; Etxebarria, G. Regional Innovation Systems: Institutional and Organisational Dimensions. Res. Policy 1997, 26, 475-491. [CrossRef]

49. Cooke, P. Regionally Asymmetric Knowledge Capabilities and Open Innovation: Exploring “Globalisation 2"-A New Model of Industry Organisation. Res. Policy 2005, 34, 1128-1149. [CrossRef]

50. Metaxiotis, K.; Carrillo, J.; Yigitcanlar, T. (Eds.) Knowledge-Based Development for Cities and Societies: An Integrated Multi-Level Approach; IGI Global: Hersey, PA, USA, 2010.

51. Pancholi, S.; Yigitcanlar, T.; Guaralda, M. Public space design of knowledge and innovation spaces: Learnings from Kelvin Grove Urban Village, Brisbane. J. Open Innov. Technol. Market Complex. 2015, 1, 13. [CrossRef]

52. Ferrary, M. Specialized Organizations and Ambidextrous Clusters in the Open Innovation Paradigm. Eur. Manag. J. 2011, 29, 181-192. [CrossRef]

53. Belussi, F.; Sammarra, A.; Sedita, S.R. Learning at the Boundaries in an "Open Regional Innovation System": A Focus on Firms' Innovation Strategies in the Emilia Romagna Life Science Industry. Res. Policy 2010, 39, 710-721. [CrossRef]

54. Cooke, P. Regional Knowledge Capabilities and Open Innovation: Regional Innovation Systems and Clusters in the Asymmetric Knowledge Economy. In Clusters, Networks and Innovation; OUP Oxford: Oxford, UK, 2005; pp. 80-109.

55. Glaeser, E.L.; Kallal, H.D.; Scheinkman, J.A.; Shleifer, A. Growth in Cities. J. Political Econ. 1992, 100, 1126-1152. [CrossRef]

56. Messeni, A.; Albino, V.; Carbonara, N.; Rotolo, D. Leveraging learning behavior and network structure to improve knowledge gatekeepers' performance. J. Knowl. Manag. 2010, 14, 635-658. [CrossRef]

57. Foucault, M. Surveiller et Punir. Naissance de la Prison; Editions Gallimard: Paris, France, 1975.

58. Ford, H. My Life and Work; Cosimo, Inc.: New York, NY, USA, 2007; pp. 54, 55, 61.

59. Schoenberger, E. From Fordism to flexible accumulation: Technology, competitive strategies, and international location. Environ. Plan. D Soc. Space 1988, 6, 245-262. [CrossRef]

60. Jessop, B. The transition to post-Fordism and the Schumpeterian workfare state. In Towards a Post-Fordist Welfare State; Routledge: Abingdon, UK, 1994; Volume 7, pp. 13-37.

61. Lander, E.; Liker, J.K. The Toyota Production System and art: Making highly customized and creative products the Toyota way. Int. J. Prod. Res. 2007, 45, 3681-3698. [CrossRef]

62. Black, J. Design rules for implementing the Toyota Production System. Int. J. Prod. Res. 2007, 45, 3639-3664. [CrossRef]

63. Ward, A.; Liker, J.K.; Cristiano, J.J.; Sobek, D.K. The second Toyota paradox: How delaying decisions can make better cars faster. Sloan Manag. Rev. 1995, 36, 43.

64. Mehri, D. The darker side of lean: An insider's perspective on the realities of the Toyota production system. Acad. Manag. Perspect. 2006, 20, 21-42. [CrossRef]

65. Adler, P.S.; Goldoftas, B.; Levine, D.I. Flexibility versus efficiency? A case study of model changeovers in the Toyota production system. Organ. Sci. 1999, 10, 43-68. [CrossRef]

66. Hampson, I. Lean Production and the Toyota Production System Or, the Case of the Forgoften Production Concepts. Econ. Ind. Democr. 1999, 20, 369-391. [CrossRef]

67. Liker, J.K.; Franz, J.K. The Toyota Way to Continuous Improvement: Linking Strategy and Operational Excellence to Achieve Superior Performance; McGraw Hill Professional: New Your, NY, USA, 2011; p. 9.

68. Hoseus, M.; Liker, J. Toyota Culture: The Heart and Soul of the Toyota Way; McGrawHill: New York, NY, USA, 2008; Volume 52.

69. Satō, M. The Toyota Leaders: An Executive Guide; Vertical Incorporated: New York, NY, USA, 2008; Volume 61.

70. Gartman, D. Three ages of the automobile: The cultural logics of the car. Theory Cult. Soc. 2004, 21, 169-195. [CrossRef] 
71. Calabrese, G. Structure and transformation of the Italian car styling supply chain. Int. J. Veh. Des. 2011, 57, 212-229. [CrossRef]

72. Christensen, T.B. Modularised eco-innovation in the auto industry. J. Clean. Prod. 2011, 19, $212-220$. [CrossRef]

73. Tsoumas, J. The Ideal of Handicrafts and the Modern Design Formation: Coincidences and Failures. METU J. Fac. Archit. 2016, 30. [CrossRef]

74. Pugh, P. The Magic of a Name: The Rolls-Royce Story, Part 2: The Power Behind the Jets; Icon Books Ltd.: London, UK, 2015; p. 157.

75. Cole, R.E. From continuous improvement to continuous innovation. Qual. Manag. J. 2001, 8, 7-21. [CrossRef]

76. Suri, R. Quick Response Manufacturing: A Companywide Approach to Reducing Lead Times; CRC Press: Boca Raton, FL, USA, 1998; p. 41.

77. Deitz, D. Rolls-Royce: Crafting a car with CAD. Mech. Eng. 1990, 112, 28.

78. Pancholi, S.; Yigitcanlar, T.; Guaralda, M. Place Making Facilitators of Knowledge and Innovation Spaces: Insights from European Best Practices. Int. J. Knowl.-Based Dev. 2015, 6, 215-240. [CrossRef]

79. Pancholi, S.; Yigitcanlar, T.; Guaralda, M. Governance that matters: Identifying place-making challenges of Melbourne's Monash Employment Cluster. J. Place Manag. Dev. 2017, 10, 73-87. [CrossRef]

80. Pancholi, S.; Yigitcanlar, T.; Guaralda, M. Place Making in Knowledge and Innovation Spaces: The Australia experience. Technol. Forecast. Soc. Chang. 2017. [CrossRef]

81. Trindade, E.P.; Hinnig, M.P.F.; da Costa, E.M.; Marques, J.S.; Bastos, R.C.; Yigitcanlar, T. Sustainable development of smart cities: A systematic review of the literature. J. Open Innov. Technol. Market Complex. 2017, 3, 11. [CrossRef]

82. Esmaeilpoorarabi, N.; Yigitcanlar, T.; Guaralda, M.; Kamruzzaman, M. Does place quality matter for innovation districts? Determining the essential place characteristics from Brisbane's knowledge precincts. Land Use Policy 2018, 79, 734-747. [CrossRef]

83. Esmaeilpoorarabi, N.; Yigitcanlar, T.; Guaralda, M.; Kamruzzaman, M. Evaluating place quality in innovation districts: A Delphic hierarchy process approach. Land Use Policy 2018, 76, 471-486. [CrossRef]

84. Esmaeilpoorarabi, N.; Yigitcanlar, T.; Guaralda, M. Place quality in innovation clusters: An empirical analysis of global best practices from Singapore, Helsinki, New York, and Sydney. Cities 2018, 74, 156-168. [CrossRef]

85. Pancholi, S.; Yigitcanlar, T.; Guaralda, M. Societal integration that matters: Place making experience of Macquarie Park Innovation District, Sydney. City Cult. Soc. 2018, 13, 13-21. [CrossRef]

86. Pancholi, S.; Yigitcanlar, T.; Guaralda, M. Attributes of successful place making in knowledge and innovation spaces: Evidence from Brisbane's Diamantina Knowledge Precinct. J. Urban Des. 2018, 23, 693-711. [CrossRef]

87. Bergvall-Kareborn, B.; Stahlbrost, A. Living Lab: An Open and Citizen-Centric Approach for Innovation. Int. J. Innovation Reg. Dev. 2009, 1, 356-370. [CrossRef]

88. Morrison, P.D.; Roberts, J.H.; Von Hippel, E. Determinants of User Innovation and Innovation Sharing in a Local Market. Manag. Sci. 2000, 46, 1513-1527. [CrossRef]

89. Prahalad, C.K.; Ramaswamy, V. Co-Creation experiences: The Next Practice in Value Creation. J. Interact. Market. 2004, 18, 5-14. [CrossRef]

90. Von Hippel, E. Innovation by User Communities: Learning From Open-Source Software. MIT Sloan Manag. Rev. 2001, 42, 82.

91. Nonaka, I. A Dynamic Theory of Organizational Knowledge Creation Organization Science; Elsevier: Amsterdam, The Netherlands, 1994; pp. 14-37.

92. Yun, J.J.; Yun, J.J.; Park, K.; Park, K.; Yang, J.; Yang, J.; Jung, W. The Philosophy of “Open Innovation” Historical Development of the Philosophy of Open Innovation and Its Reflection from Taoism. J. Sci. Technol. Policy Manag. 2016, 7, 134-153. [CrossRef]

93. Complete Graph. Available online: https://en.wikipedia.org/wiki/Complete_graph (accessed on 5 August 2018).

(C) 2018 by the authors. Licensee MDPI, Basel, Switzerland. This article is an open access article distributed under the terms and conditions of the Creative Commons Attribution (CC BY) license (http:/ / creativecommons.org/licenses/by/4.0/). 